GERRARD INDIA BAZAAR: AN ATYPICAL ETHNIC ECONOMY IN A RESIDENTIAL NEIGHBOURHOOD

\author{
by \\ Angelica Suorineni, Honours B.A., Laurentian University, 2009 \\ A Major Research Paper \\ presented to Ryerson University \\ in partial fulfillment of the requirements for the degree of \\ Master of Arts \\ in the Program of \\ Immigration and Settlement Studies
}

Toronto, Ontario, Canada, 2010 


\section{Author's Declaration}

I hereby declare that I am the sole author of this major research paper.

I authorize Ryerson University to lend this paper to other institutions or individuals for the purpose of scholarly research.

I further authorize Ryerson University to reproduce this paper by photocopying or by other means, in total or in part, at the request of other institutions or individuals for the purpose of scholarly research.

$\overline{\text { Signature }}$ 


\title{
GERRARD INDIA BAZAAR: AN ATYPICAL ETHNIC ECONOMY IN A RESIDENTIAL NEIGHBOURHOOD
}

(C) Angelica Suorineni 2010

Master of Arts

Immigration and Settlement Studies

Ryerson University

\begin{abstract}
The purpose of this study is to examine the validity of the thesis that ethnic economies develop from a co-ethnic residential context. This paper presents the Gerrard India Bazaar located at Gerrard Street East and Coxwell Ave in Toronto, Ontario, as a South Asian ethnic economy that has developed into an ethnic commercial district without a corresponding coethnic neighborhood. This paper explores the process and challenges that have accompanied the development of the Gerrard India Bazaar with the use of newspaper documentation on the area and business information from 1971, 1982, 1991, 1996, 1999 and 2009 MIGHTS Business Directory and 1976, 1986, 1996 and 2006 Census Data on the area. Findings from the research demonstrate that ethnic economies can be sustained without a co-ethnic neighborhood as long as there is co-occurring emergence of formal aspects of institutional completeness, accommodation to the residential environment and marketability to the mainstream market.
\end{abstract}

Keywords: ethnic economy, South Asian, India Bazaar, institutional completeness, neighbourhood 


\section{Acknowledgements}

The author would like to acknowledge the input of various individuals, without which this project would not have occurred:

I would like to thank Dr. Harald Bauder for all his help and unwavering support in supervising me throughout the year and throughout the completion of this MRP. Also, I would like to thank my second reader Dr. Sutama Ghosh for their complementary recommendations.

I would also like to thank Mom (Agnes), Dad (Fidelis) and Josephine Suorineni for their love, encouragement and support, I am very grateful to have parents and siblings like you.

Thanks also to all my other friends and family for their support. 


\section{Dedications}

Last but not least, I dedicate this MRP to Anthea Esther Pascalina Zaghe, John Suorineni, Justina Zaghe, Cynthia Zaghe, Maurice Zaghe, Blaise Zaghe, Emilio Dakyie, Songpore Suorineni, Pierrema Aboiakansu, and Michael Zaghe. Each and every one made a significant mark in my life during the short time I got to know them. They offered me nothing but love, kindness and support, something that I will always cherish. May your souls rest in peace. 


\section{Table of Contents}

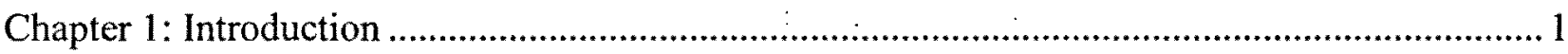

Chapter 2: Literature Review \& Theoretical Frameworks............................................................... 4

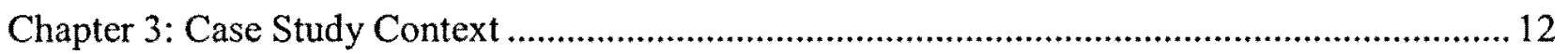

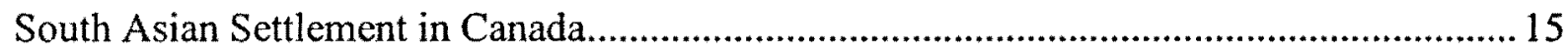

South Asian Settlement in Toronto, Ontario .................................................................... 15

Development of Gerrard India Bazaar........................................................................... 18

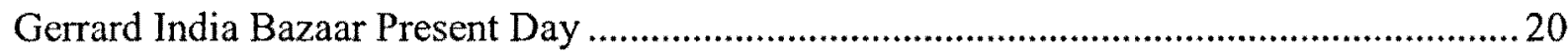

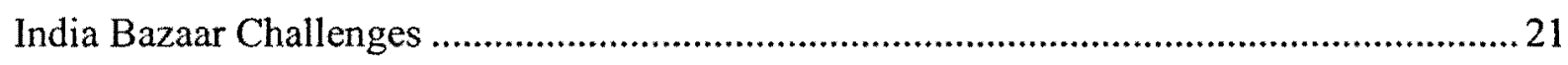

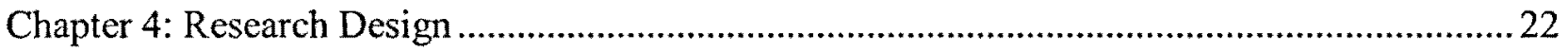

Scope

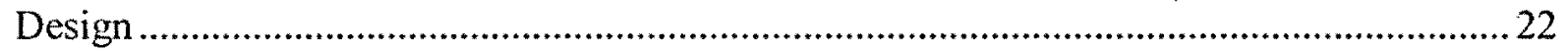

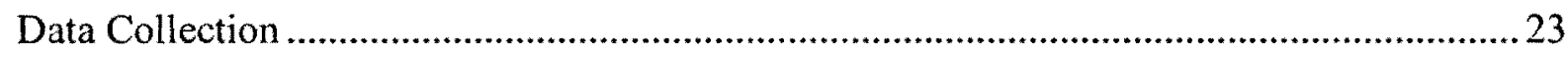

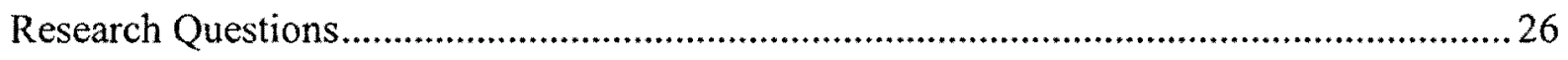

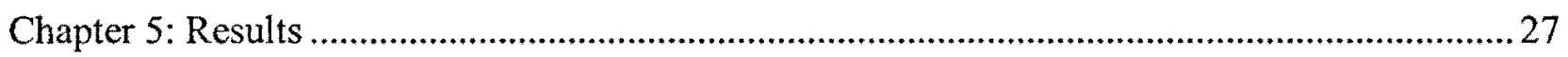

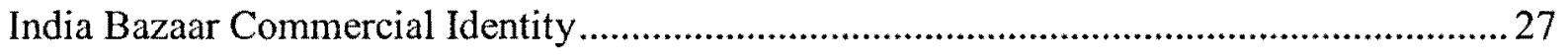

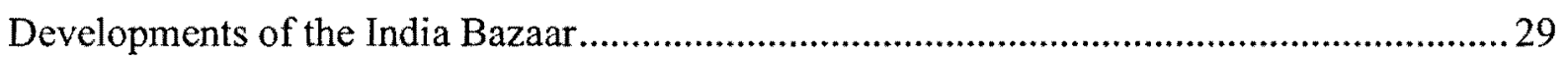

Image of the India Bazaar to the Local and International South Asian Community.............. 34

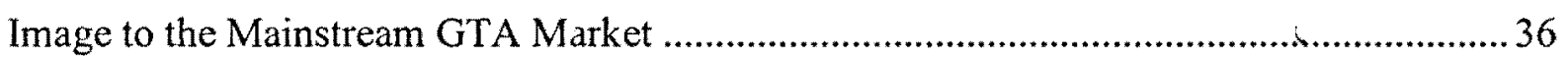

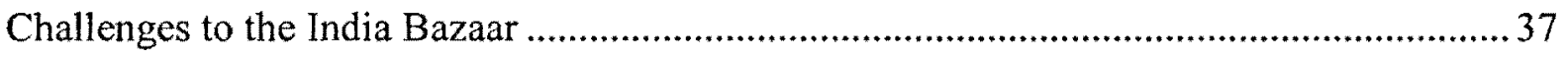

Gerrard Street East and Coxwell Avenue: Residential History and Development ................ 38

Residential Impact on the India Bazaar ...........................................................................4 44

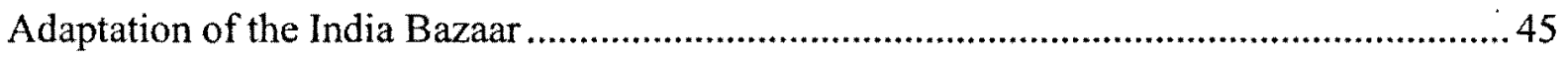

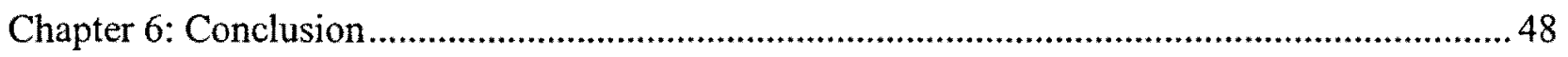

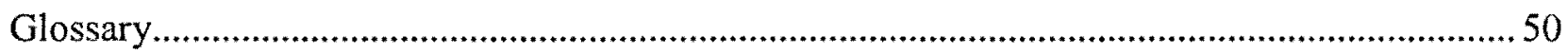

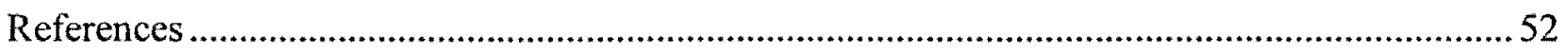




\section{List of Tables}

Table 1: Businesses on Gerrard Street East and Coxwell Ave Area...............................................33

Table 2: 1976 Selected Census Tract Data for North and South Gerrard Street East and Coxwell Ave

Table 3: 1986 Selected Census Tract Data for North and South Gerrard Street East and Coxwell Ave 41

Table 4: 1996 Selected Census Tract Data for North and South Gerrard Street East and Coxwell Avenue

Table 5: 2006 Selected Census Tract Data on North and South Gerrard Street East and Coxwell Ave. .43

\section{Table of Figures}

Figure 1: Census Tract (CT) 0026.00 profile for Toronto (CMA) 25

Figure 2: Census Tract (CT) 0074.00 profile for Toronto (CMA) .26 


\section{Chapter 1: Introduction}

The entrepreneurship of newcomers in the receiving country has been a common avenue to make a better life. The ethnic market provides a window of opportunity towards financial stability for some newcomers in the receiving society, in such a case the probability of success is primarily determined by the size of the ethnic community, where the "bigger the better" (Lo et al., 2001). Immigrant entrepreneurship has usually resulted from demands for goods and services by a spatially concentrated immigrant community (Price \& Chacko, 2009). Consequently, an ethnic cnclave is developed consisting of a bilateral relationship between the ethnic businesses that are established and organized to serve their coethnic market within the spatially concentrated immigrant community (Portes \& Bach, 1985). Research shows that the success of an ethnic business is dependent upon historical and cultural factors in the receiving country (Light \& Rosenstein, 1995; Teixeira, 2007). Factors based on the history of ethnic relations in the receiving country, length of time the ethnic group has been established in the receiving country and presence or absence of businesses catering to the ethnic community have been found to be relevant to immigrant entrepreneurship ( $\mathrm{Li}, 2001$; Teixeira, 2007). In addition, cultural factors such as ethnic solidarity, type of family organization and the presence of community institutions that provide social and monetary support have been found to be equally as important (Lo et al., 2001; Kloosterman \& Rath, 2001; Qadeer, 1999). Indeed, the socioeconomic structure of an ethnic community has been identified as a primary indicator of the success of an ethnic commercial enclave and the businesses within it. Specifically, ethnic groups that generate subeconomies involving available labour and access to capital and demands for distinct cultural products ensure a higher likelihood of success for its ethnic entrepreneurs (Hiebert, 2003; 
Qadeer, 1999). In other words, the likelihood of success of an ethnic entrepreneur depends on a dynamic interaction of social, economic and institutional factors. Therefore, what is known as an ethnic subeconomy thrives when there is a cohesive ethnic economy accompanied by institutional completeness. A strong dynamic relationship helps decrease the vulnerability of the ethnic economy and its associated subeconomies from external conditions (i.e. markets, competition and policy) (Hiebert, 2003), in light of these external threats, the ethnic economy is shielded by strategies (i.e. ethnic strategies) of the ethnic community that consist of plans and tactics that take advantage of own-group characteristics and structures. However, it has been suggested that the strength of these ethnic strategies depends to some extent, on the solidarity of the ethnic community and its ability to establish effective strategies to fulfill the economic goals of their ethnic commercial enclaves (Marger \& Hoffman, 1992; Qadeer, 1999; Ram et al., 2002).

Ethnic entrepreneurship has been identified as a crucial factor in the restructuring of current Western industrial economies. Specifically, the activity of ethnic entrepreneurs at the community level indirectly influences the restructuring and development of the receiving country's economy (Teixeira, 2001). For example, the act of an immigrant establishing a business helps enclave economies and ethnic economies develop by generating their own demand for items, such as immigration (Light, 2004). The current research examines the influence of ethnic entrepreneurial activity from the South Asian commercial space of the Gerrard India Bazaar. Focusing on the impact of a specific ethnic group's commercial presence in a neighbourhood context can highlight the contributions and dynamics that make it similar or unique to other ethnic commercial spaces. Lo et al. (2001) reveal that differences exist among immigrant groups when it comes to self-employment in the receiving country. Some ethnic groups seem to be more entrepreneurially inclined than others. In Toronto, the rate of self- 
employment among immigrant groups is generally higher for those of European descent, such as the Polish, German and Jewish immigrant populations. On the other hand, the least entrepreneurial immigrant groups consist mostly of visible minority groups, specifically Caribbean, Southeast Asian and African immigrant groups. While some studies have attempted to examine the position of visible minority immigrant groups in an entrepreneurial context from a neighbourhood standpoint (Oliviera, 2000), few studies are conducted on the entrepreneurial activities of visible minorities ethnic economies in areas that do not residentially correlate. This paper explores the development of South Asian ethnic entrepreneurship in Toronto, Ontario's Gerrard/Coxwell India Bazaar. The India Bazaar, also commonly known as "Little India", is an area with an established South Asian commercial identity but no accompanying residential identity. For the purposes of this study, the term South Asian will be used throughout the paper to be used as an ethnocultural term in reference to people who come from countries that comprise of Southern Asia; the term is not intended to denote a nationality or ethnicity. The paper also analyzes the immigration factors that influence the state of the area's commercial identity in relation to its residential environment. The purpose of the paper is to explore the validity of theory that ethnic economies emerge from a co-ethnic neighbourhood context by presenting the case of the Gerrard India Bazaar. Primary research questions of the study are: How is the India Bazaar able to develop without a residential presence of coethnics? What are the contributing factors and challenges that are involved in the development of the India Bazaar's commercial identity as a South Asian marketplace? The current paper argues that an ethnic economy situated in a non-coethnic neighbourhood can function accordingly as long as there is the availability of other reinforcing factors. 


\section{Chapter 2: Literature Review \& Theoretical Frameworks}

There are prevalent theories that explain the development of ethnic economies. All of which are based on the assumption that the ethnic residential identity of a neighbourhood precedes that of the ethnic commercial identity situated within the neighbourhood. Levels of involvement of ethnic entrepreneurship among immigrant groups tend to vary, with the least active belonging to visible minorities (Lo et al., 2001). Some theories explain the success and differences of enclave economies and ethnic economies are based on structural and cultural factors (Teixeira, 2001). The cultural standpoints used to explain enclave economies and ethnic economies asserts that ethnic minorities enter entrepreneurship because of cultural characteristics that are conducive to entrepreneurship such as family-group mutual support (Zenner, 1991; Teixeira, 2007). This includes theories such as enclave theory and middleman theory. Enclave theory is based on the premise that ethnic communities are self-sufficient, in that the enclave represents a community consisting of residences and businesses, which generates a segmented economy of primary and secondary employment. This structure allows for ethnic entrepreneurs in the enclave to reproduce the segmented labour market of the dominant society: In this way, the enclave provides another alternative of upward social mobility among migrants within the ethnic community (Portes \& Bach, 1985; Zhou, 1992; Qadeer \& Kumar, 2003). According to middleman theory ethnic entrepreneurs tend to be self-employed as the middlemen in occupations such as rent collectors, contractors and brokers in order to facilitate the purchase of products between producer and consumers, the elite and the masses, etc (Bonacich, 1973; Bonacich \& Modell, 1980; Zenner, 1991). Particularly, the theory contends that the nature of their "middleman" role in a transitional occupation is because these migrant entrepreneurs do not intend to stay in the area permanently. Consequently, the theory refers to their occupational 
status as a "sojourner orientation". The theory also states that these 'middlemen' come from backgrounds of distinct cultural and social characteristics that promote solidarity in combination with having distinct economic traits. The theory infers that ethnic entrepreneurial activity is based on the assumption that entrepreneurship emerges at the community level where there is a mutual migration experience with co-ethnics (Bonacich, 1973; Bonacich \& Modell, 1980). Cultural perspectives may explain the differences of involvement within immigrant groups and the differences between immigrant groups and dominant society (Teixeira, 2001), but they do not adequately explain why these patterns are not persistent in the context of recent ethnic immigrants. Specifically, some traditional immigrant groups typically known for high rates of self-employment in the receiving country are decreasing and are residing and establishing businesses in areas that are not traditionally related to their established enclaves. For instance, studies have found that recent Portuguese entrepreneurs are less likely to establish businesses in the traditional "Little Portugal" area where there once was a large Portuguese community but are now settling and establishing businesses in the Mississauga suburb of Toronto (Teixeira, 2007). This behaviour correlates with the trend of recent entrepreneurial immigrants establishing firms in suburbs, where entrepreneurial opportunities are considered to be few (Teixiera, 2007; Rangaswamy, 2007). Researchers argue that ethnic entrepreneurship without expansion of the ethnic commercial space is an effective mobility trap that leads to lower earnings among selfemployed immigrants in relation to their own human capital due to sharing increasingly small profit margins, a limited customer base and suppliers (Portes \& Jensen, 1989; Oliviera, 2000). Similarly, Kloosterman and Rath (2001) point out that ethnic entrepreneurial businesses tend to be located in the lower end of the sectors they occupy and are faced with the challenges of adapting to and creating opportunities for growth in the urban economy. In some cases, these 
challenges are intensified when the businesses of the ethnic entrepreneurs operate within markets that are saturated with co-ethnic businesses. Consequently, this creates difficulty of maintaining labour supply of co-ethnics (Kloosterman and Rath, 2001). Researchers have found that the while the South Asian community tends to value family and co-ethnic workers as viable resources in the running of their small businesses, a quality considered to be conducive to the ethnic economy because it supplies cheap or unpaid labour to cut down operational and start-up costs, these resources are not exhaustively used (Lo et al., 2004).

Qadeer (1999) found that class and personal resources were more important factors for entrepreneurial behaviour among ethnic groups than cultural inclinations towards selfemployment. Bauder's (2008) research also presents an alternative view to the common understanding that some immigrant groups are culturally predisposed to entrepreneurship in the receiving country. His study reveals that, while it is correct to indicate origin in the propensity of entrepreneurship, it is regional origin as opposed to cultural origin that plays a crucial factor. That is rural-urban background; those from urban backgrounds are associated with a low desire for entrepreneurship because of assimilation to wage labour, whereas those with rural backgrounds were more inclined to self-employment because of a decreased exposure to wage labour and a value-based commitment to the economic well being of their family unit as opposed to individual family members.

Similar to Bauder (2008), Qadeer (1999) casts doubt on the belief that ethnicity and culture plays a pivotal role on entrepreneurial behaviour in the receiving country. Indeed, in the case of the UK, the phenomenon of shrinking South Asian self-employment has been attributed to the acquisition of higher educational qualifications providing a leverage for entrance into professional and managerial positions, self-employment within the group is a matter of choice as 
opposed to structural and economic coercion-especially for subsequent generations of UK-born South Asians who do not have the barriers (i.e. language skills, lack of foreign credential recognition, lack of recognition for out of country work experience, etc) that previous generations encountered. The reluctance of second generation UK born South Asians to continue in self-employment is thought to be the result of encouragement to subsequent generations by their first generation parents to enter professional occupations (Jones \& Ram, 2003). Similarly, Rangaswamy (2007) examined immigrant self employment and niche development. Particularly, the prevalence of South Asian owned and operated Dunkin Donuts franchises in the American Midwest. She found that these business operated on the use of ethnic resources of family (i.e. using women in the family as customer service employees to create a rapport with customers) and from co-ethnics in addition to strategizing to attract external financial investment represented a dynamic business strategy of capitalizing on the resources they had available to them to ensure the success of the franchise. It was found that the entrepreneurs took advantage of the lack of enforcement by immigration authorities to maintain their unauthorized labour force and they took advantage of the company's policy structure on expansion. Thus, ethnic entrepreneurs take advantage of ethnic resources when it is advantageous and practical and not because of cultural predisposition.

Similar to Oliviera (2000), Marger and Hoffman (1992) established that India Bazaar entrepreneurs engaged in an individualistic pattern of operating their ethnic enterprises. This result is consistent with the findings of Bauder (2008) and Li (2000). Barrett, Jones \& McEvoy assert that the longevity of ethnic firms that constitute ethnic commercial spaces depends on the decrease of reliance on internal markets (e.g. coethnic customers). Structural explanations single out racial discrimination in the receiving country as a force that disadvantages ethnic minorities 
by inhibiting their advancement into certain labour markets, from this perspective the entrance of immigrants into entrepreneurship is a reactionary response to lack of employment and low wages. These theories include, protected market hypothesis, blocked mobility hypothesis, residential succession model and the invasion succession model.

The protected market hypothesis presents ethnic entrepreneurship in enclaves as a beneficial strategy, where ethnic residential concentration provides a practical and convenient consumer source for ethnic entrepreneurs. It also presumes that ethnic clustering provides recruitment networks for ethnic suppliers and networks (Aldrich \& Waldinger, 1990; Light, 2004). Correspondingly, Kloosterman and Rath (2001) acknowledge that immigrant entrepreneurs are more likely to encounter difficulties maintaining supply when their businesses are established in areas that are not close to neighbourhoods with a substantial concentration of co ethnics. Similarly, Marger and Hoffman (1992) stress the importance of institutional completeness in maintaining an ethnic commercial space. Ethnic enclaves are understood to provide protected markets for ethnic entrepreneurs because they provide a geographically concentrated customer base to generate profit as well as foster interlinkages among coethnics, customers, employers and employees. Blocked mobility hypothesis contends that entrepreneurship results from barriers into the waged labour market, under this context immigrants open businesses due to barriers such as limited language skills, lack of foreign credential recognition, or racial and ethnic discrimination (Price \& Chacko, 2009). According to the residential succession model's application to ethnic entrepreneurship, ethnic groups succeed one another. First, through assuming vacancies in the residential neighbourhood left by other ethnic groups and then the ethnic entrepreneurs assuming vacancies of business establishments left in the neighbourhood (Waldinger et al., 1985). Similar to the residential succession model is 
the invasion succession model, which emphasizes the ethnic transition of neighbourhoods over time (Hou \& Milan, 2003). Aside from the assumption of a residential community preceding the ethnic economy, these theories outline the pattern of ethnic entrepreneurship within ethnic economies. First, there is movement into an area of co-ethnics, then the migrant group experiences restrictions of access to economic opportunities in the primary labour market due to barriers (i.e. language fluency, foreign credential recognition) (Light \& Rosenstein, 1995). Thus, in order to inhibit economic failure, some newcomers establish ethnic enterprises. Researchers have identified three crucial components for the durability of ethnic businesses. First, there needs to be a niche that the small business can fulfill. Secondly, the immigrant needs access to ownership opportunities. Lastly, the immigrant needs resources to capitalize upon the ownership opportunities (Waldinger et al., 1985). In a broader context, some researchers argue that businesses owned by co-ethnics within the enclave not only increase the number and type of potential customers but also strengthens the ethnic community's social structure (Zhou, 2006). Light (2004) reflects this argument by characterizing enclave economies as creators of a sense of cultural community. In the case of the India Bazaar, the ethnic entrepreneurs not only consist of East Indians but also those from Pakistan and Bangladesh who may have similar but distinct cultural traits (Qadeer, 1999). The term 'South Asian' functions as an umbrella word to represent subethinicties from the Indian subcontinent, however these subethnicities do not necessarily share the same religion, practices and at times carry pre-existing political and social conflicts towards one another. Thus, the term South Asian is too broad a term to represent the subethnicities captured by the term, which is problematic because it facilitates overlooking important patterns that are not attributable to South Asians as a group. 
The relationship between location and functionality of the ethnic enterprise or ethnic commercial area can be a paradoxical one. Researchers caution that while ethnic commercial enclaves insulate ethnic firms by acting as a protected market. They can also become a trap that confines growth, resulting in an 'economic dead-end' for the ethnic entrepreneurs (Qadeer, 1999; Waldinger, 1986). Being in an 'economic dead-end' can force ethnic entrepreneurs to intensify the practice of exploiting themselves as a business strategy (i.e. open for longer hours, year round operation, offering easily available credit) (Jones \& Ram, 2003). Other research points to the location of the ethnic commercial space to its co-ethnics may also limit profitability and growth of the ethnic enterprise, specifically, the placement of ethnic firms in poor neighbourhoods (Jones et al., 2002). Considering the working class history of the Gerrard and Coxwell neighbourhood, Oliveira (2000) found that the customers she interviewed at the India Bazaar were mostly from the suburbs of Scarborough and did not frequent the Bazaar for their day to day shopping. Instead they preferred to shop at mainstream markets that were closer to them due to the lessened commute and the provision of ethnic goods at mainstream stores, which the need to shop at ethnic commercial spaces such as the India Bazaar.

Since its inception in the 1970 s the India Bazaar shows wear and tear, in relation to the time of its peak where the streets were lined with fully functioning and thriving South Asian businesses (Brouse, 2005; Stein, 1984, Snider, 1984; Bruzal, 1982; Leroy, 1978). The commercial identity of the area has been undergoing some declination for years (Qadeer, 1999; Marger \& Hoffman, 1992; Oliveira, 2000). The decline in ethnic entrepreneurship in the area can be linked to differences in educational attainment between South Asian cohorts that immigrated to the Toronto area in the 1970s and current South Asian cohorts immigrating to Toronto (Hou \& 
Milan, 2003; Marger \& Hoffman, 1992; Tran et al., 2005, Qadeer, 1999). That is, current South Asian migrants to Canada generally have higher educational attainment and professional backgrounds compared to their 1970s counterparts (Tran et al., 2005 Qadeer, 1999). These attainments may deter migrants from pursuing the establishment of small firms in retail or the restaurant industry, where so many ethnic businesses are represented (Lo et al., 2001; Waldinger et al., 1981). Furthermore, research emphasizes the strength of institutional completeness with facilitating the longevity of ethnic commercial spaces (Qadeer, 1999; Price \& Chacko, 2009). That said, South Asians in Toronto have been identified to have unattached co-ethnic community bonds, likely associated with the fragmentation of sub-nationalities within the South Asian classification (Tran et al., 2005; Qadeer, 1999). Thus, considering the decline of the South Asian businesses in the area, its commercial identity as a South Asian marketplace at the Gerrard and Coxwell neighbourhood has been called into question (Qadeer, 1999; Oliviera, 2000). For instance, in its commissioned neighbourhood map of Toronto, the Toronto Star newspaper did not assign the India Bazaar region any distinct identity. In fact, the area that is considered the India Bazaar was amalgamated into the adjacent 'Leslieville' neighbourhood (Kidd, 2009). Hence, the failure to recognize the area's ethnic component reinforces the argument that the South Asian commercial presence has not been fully substantiated by dominant society.

Structural theories concerning enclave and ethnic economies, such as the blocked mobility hypotheses are criticized for inadequately explaining the varied levels of involvement in ethnic entrepreneurship among ethnic minority groups. Specifically, these theoretical frameworks are criticized for not adequately addressing the results of lower levels of involvement with self-employment among some visible minority groups (Teixeira, 2001). 
Indeed, $\mathrm{Li}(2001)$ provides an alternative explanation to the blocked mobility hypothesis. His research found that recent immigrants are no longer coerced into business for economic survival. The integrative approach is a framework that examines ethnic entrepreneurship from both cultural and structural factors. The integrative approach explains that the reason for entrance into the entrepreneurship sector for ethnic minorities is due both to opportunity structures and to group characteristics (Teixeira, 2001). In the U.S context, Raijman and Tienda (2000) found that South Asian entrepreneurs became self-employed because it was consistent with their preexisting experiences of self-employment in their country of origin. These entrepreneurs acquired the relevant business skills in previous occupations. Furthermore, irrespective of socioeconomic level, all the South Asian entrepreneurs perceived self-employment as a way to economic mobility.

\section{Chapter 3: Case Study Context}

Though the pattern of entrepreneurial establishment can be typified for most ethnic economies, research on the India Bazaar reveals the manifestation of an ethnic economy that contradicts the prevailing theories in two ways. First, the commercial identity of the India Bazaar was established before there was any residential presence of South Asians in the area. Secondly, ethnic entrepreneurs of the area tend to adopt an individualist approach to self-employment, an approach that contradicts the observed group characteristics of the South Asian culture Gones \& Ram, 2003; Qadeer, 1999; Marger \& Hoffman, 1992; Ram et al., 2002; Oliveira, 2000). In addition, the name India Bazaar is misleading because there are other entrepreneurs with nationalities of South Asian background who operate businesses in the area, in contrast to traditional ethnic economies which represented a homogeneous group of people from the same 
cultural and linguistic background (e.g. Little Italy, Little Portugal, Chinatown) (Qadeer, 1999; Oliviera, 2000; Brouse, 2005; Marger \& Hoffman, 1992).

The ethnic entrepreneurs of the India Bazaar have been found to employ a more individualistic approach regarding their business activities, unrepresentative of their typical cultural characteristics. That is, choosing to intentionally limit the extent of utilizing ethnic resources as opposed to exploiting the use of ethnic resources (Marger \& Hoffman, 1992; Rangaswamy, 2007; Oliveira, 2000). Research indicates that India Bazaar merchants pre-empted selfemployment prior to entry in the receiving country, most establishing necessary start-up capital before arrival or saving up while employed in other occupations in the receiving country (Oliveira, 2000; Qadeer, 1999). Particularly, Qadeer (1999) concludes that the presence of ethnic resources is not a defining element for South Asian entrepreneurs in Toronto, who tend to use ethnic resources only when it is practical to do so. For example, $66.7 \%$ of the South Asian entrepreneurs in Qadeer's (1999) study reported the use of coethnics from country of origin as suppliers because it eliminated linguistic difficulties and because transactions were based on mutual trust. Thus, the use of ethnic resources was not indicative of entrepreneurial behaviour but facilitated it (Price \& Chacko, 2009).

Qadeer (1999) revealed that the South Asian entrepreneurs in Toronto's ethnic commercial spaces usually used their own personal savings $(95.6 \%)$ to establish their businesses and were reluctant to depend on external sources. Furthermore, $80 \%$ of the South Asian entrepreneurs in his study established their businesses from 'scratch', $77 \%$ wanted to be self-employed in order to achieve economic independence and $78 \%$ intended on maintaining and expanding their businesses. Thus, the motivation to establish business by contemporary visible minority groups 
no longer appears to be based on economic survival, indicating that the blocked mobility hypothesis needs to be revised.

Nevertheless, the oldest ethnic business centre for South Asians in Toronto has been the Gerrard/Coxwell India Bazaar (Qadeer, 1999; Oliveira, 2000). Since its inception, it predominately caters to South Asian clientele, whereas most clusters of South Asian oriented business tend to cater primarily to an ethnically mixed clientele (Oliveira, 2000; Lo et al., 2001; Qadeer, 1999). According to Oliviera (2000), the ethnic entrepreneurs of the India Bazaar were not motivated to live an 'Indian Life' in Toronto. Thus, she argued that the choice of entrepreneurship was a decision based on practicality and self-motivation. Oliveira (2000) found that choice of entrepreneurship could not be attributed to ethnic factors but one of practicality. The India Bazaar entrepreneurs chose to be self-employed because they were previously selfemployed in their country of origin or they had relevant occupational experiences that facilitated entrepreneurship. Thus, they felt confident in pursuing self-employment. Accordingly, Oliveira (2000) found that most of the ethnic entrepreneurs in her study had pre-existing entrepreneurial experiences and raised their own capital. The defining characteristic of India Bazaar entrepreneurs is their independent and individualistic approach to entrepreneurship. For South Asian entrepreneurs, the outcome of self-employment is perceived as an avenue to economic mobility. According to Waldinger (1993), market conditions and social processes have an ongoing influence on the success of an ethnic business. Thus, in the broader context the retainment of the India Bazaar's commercial identity depends in large part on the ability of the ethnic businesses in the area to adapt to the social processes and market conditions that relate to them within the urban economy. 


\section{South Asian Settlement in Canada}

Prior to the mid 1960s few immigrants of South Asian descent resided in Canada, which at the time mostly consisted of a Sikh population living in British Columbia (Tran et al., 2005; Oliveira, 2000). Currently, not only is the South Asian visible minority group one of the largest in Canada, it is also the most diverse with a variety of ethnic, linguistic and religious subgroups (Tran et al., 2005). Furthermore, the South Asian group is one that has a growing young population consisting of children and young adults (Lindsay, 2001).

The settlement pattern of South Asians in Canada is not conducive to enclave formation. According to their Canadian study, Hou and Milan (2003) found that the proportion of South Asians increased in neighbourhoods with large proportions of Chinese and smaller proportions of Whites. This settlement activity contradicted their proposed invasion succession model of settlement for ethnic minorities. The invasion succession model argues that ethnic minorities, such as South Asians tend to partially replace neighbourhoods with established White residents. Furthermore, South Asians tended to belong to a group of ethnic minorities that chose to live close to members of the same ethnic background out of convenience because of a preference to have social interactions with co-ethnics, while others settled among co-ethnics because of cultural or linguistic barriers that inhibit interaction with the majority population (Hou \& Milan, 2003). In other words, contemporary settlement patterns of some visible minority immigrant groups can inhibit enclave formation thought necessary for ethnic economy development.

South Asian Settlement in Toronto, Ontario 
Settlement characteristics have also been identified as an influential factor for the outcomes of ethnic enterprises in the receiving country. Particularly, the combination of local ethnic market provided by the enclave's residential clustering increases the ethnic entrepreneur's potential profits. However, the India Bazaar developed within a working class neighbourhood with predominately Anglo-Saxon residents as opposed to within a neighbourhood with a geographic concentration of co-ethnics (Oliveira, 2000; Brouse 2005, Leroy, 1978).

Researchers contend that the reason why ethnic groups differ in spatial assimilation is because they operate under different patterns (Hou, 2006; Qadeer, 1999). In 2001, South Asians accounted for $10 \%$ of Toronto's population, making them the largest visible minority group in the Toronto CMA (Census Metropolitan Area) (Tran et al., 2005). However, research reveals that South Asians are residentially dispersed all over the Toronto CMA, at times in clusters but not spatially concentrated. Clusters of South Asians tend to settle in Northwest Etobicoke, Thomcliffe/Flemington Park and Danforth/Victoria Park areas (Oliviera, 2000; Qadeer, 1999). In contrast to previously established ethnic spaces that have thrived as ethnic enclaves (e.g. "Chinatown", "Greek town", "Little Italy") that are linguistically and culturally homogenous (Oliviera, 2000; Qadeer, 1999; Lo et al., 2004). There is no pre-existing ethnic enclave for South Asians, where an enclave economy can be situated. Considering the fragmentation of ethnicities within the term 'South Asian', the result of subethnic clustering of South Asians in several areas all over the GTA is logical. For instance, there are Bangladeshi residential concentrations in Victoria Park, north of the Danforth and Punjabi-speaking residential concentrations in Malton and Brampton (Qadeer, 1999; Qadeer and Kumar, 2003). While considered to be the least segregated visible minority group in Toronto across all generations, clusters of South Asian subethnicities can be found mostly in suburban areas and metropolitan core and because these 
areas do not overlap the result has been determined to be indicative of differences in residential preference based on class resources and length of stay in Canada (Balakrishnan \& Gyimah, 2003). That said, newcomer South Asians tend to live in mixed neighbourhoods, moving from one mixed neighbourhood to another (Balakrishnan \& Gyimah, 2003; Hou, 2006). Teixeira (2001) explains that the settlement patterns of more recent racialized immigrants are more scattered than in the past, likely due to social and class divisions. In other words, newcomers from similar but heterogeneous ethnic backgrounds are less likely to settle and establish businesses in areas based on their ethnic grouping (i.e. Blacks, South Asians) (Qadeer \& Kumar, 2003; Teixeira, 2007; Qadeer, 1999). Myles and Hou (2005) also found that the longer the residence in Canada of a South Asian, the more affluent the neighbourhood is likely to be. In fact, South Asians in Toronto tend to initially settle in immigrant enclaves before moving into affluent neighbourhoods. While, recent low-income South Asian immigrants tend to live in poor immigrant enclaves with other low-income migrants (Myles \& Hou, 2005). This supports the general settlement patterns of South Asians as primarily sequential.

Essentially, South Asians as a group in Toronto do not have a residential niche and they do not have settlement patterns conducive to ethnic enclave formation. Researchers continue to strongly associate institutional completeness with the embeddedness and longevity of ethnic commercial spaces and residential concentration of an ethnic group has been associated with strengthening institutional completeness (Hou, 2006). For instance, the most residentially concentrated ethnic group in Canada are Jews and they are also considered to be one of the most institutionally complete in Canada (Balakrishnan \& Gyimah, 2003). South Asian settlement dispersion in Toronto indicates a lack of sophisticated and cohesive networks available to the 
South Asian entrepreneurs of the India Bazaar that may be available to other ethnic entrepreneurs that operate within more cohesive and homogeneous ethnic economies.

\section{Development of Gerrard India Bazaar}

Immediately before the South Asian commercial identity of Gerrard/Coxwell, it was a Greek neighbourhood with corresponding Greek businesses (Brouse, 2005; Stein, 1984). In 1971, before its identity as a South Asian commercial space, there were no South Asian businesses in the area. Of the 71 stores that were operating at the time, most were food and grocery stores, laundry and dry-cleaning and barbershop and hairdressing establishments catering to dominant society. At the time of its development into what is now considered the India Bazaar, the area was still considered to be a poor, working class neighbourhood in a deteriorating state (Oliviera, 2000). With the exit of its Greek residential and commercial presence, many stores on the main streets were left vacant, according to some reports the area was considered 'dead' and Gerrard Street East and Coxwell was lined with five or six empty storefronts at any given time (Stein, 1984). This correlates with findings that vacancies for new business owners occur as older ethnic groups that previously dominated small business in the area move into higher social positions (Waldinger et al., 1985). Accordingly, due to its deteriorating state in the 1970 s, the cost of purchasing stores in the area was among the cheapest in Toronto (Oliveira, 2002). Unlike previously established ethnic enclaves (e.g. Chinatown, Little Portugal), the Gerrard India Bazaar's ethnic commercial identity preceded its identity as an ethnic community and its relatively recent entrenchment into the Gerrard/Coxwell neighbourhood. Gian Naaz is credited with initiating the development of the Gerrard/Coxwell India Bazaar by opening a South Asian theatre in the area. Though he was educated in India with 
a degree in mechanical engineering, Naaz worked in several low-paying jobs when he arrived in Canada with his family in 1968. Eventually, he managed to save up enough money in 1974 to purchase the Eastwood Theatre on Gerrard Street East for $\$ 10,000$, which he was previously renting to show Indian films. The theatre became extremely successful attracting South Asians from Toronto and across the border and it was the only one of its kind in North America at the time. Due to the area's reputation as a poor working class neighbourhood, affluent South Asians criticized Naaz for establishing his business in the area and they avoided the area because they perceived it to be run-down and unattractive. Despite the criticism, Naaz encouraged and helped other South Asians to establish businesses in the neighbourhood. He consciously intended to establish a South Asian business district in the area because he wanted an area in the downtown core where South Asians could gather and socialize and the women could wear their saris (Paradkar, 2000). Over time, the area has come to attract many visitors, mostly of South Asian descent because it was perceived to be an authentic representation of marketplaces in South Asia (Oliveira, 2000). The commercial development of the area in the 1990s was accompanied by an emergence of Pakistani, Sri Lankan and Bangladeshi owned businesses which, broke the East Indian commercial dominance in the area. This resulted in Pakistani stores congregating west of the India Bazaar, Bangladeshi stores to the east and East Indian stores sandwiched in between (Oliveira, 2000). The atypical development and progression of the Gerrard/Coxwell's India Bazaar is reflective of current experiences of more recent immigrant groups who lack ethnic enclaves (e.g. Ethiopians in Washington, D.C) (Price \& Chacko, 2009). 


\section{Gerrard India Bazaar Present Day}

The India Bazaar continues to operate in the Gerrard/Coxwell area without a corresponding residential identity. There is no enclave of South Asians in the area and none nearby (Oliviera, 2000). However, the India Bazaar is considered to be vulnerable because it is an ethnic commercial space that lacks the geographical concentration of coethnics. Thus, the India Bazaar as an ethnic commercial space cannot be considered to be a protected commercial market. Indeed, the India Bazaar underwent a period of economic strife that resulted in the inception of the Gerrard India BIA (Business Improvement Area). The Gerrard India Bazaar has been credited with contributing to continued revitalization of the area (Stein, 1984). Another recent formal institution in the area is the presence of the ICICI Bank. The establishment of the Gerrard St East branch in 2005, indicates that the commercial ethnic identity of the area is recognized as a permanent fixture within the extended South Asian community, worthy enough to establish a multi-national financial institution that caters predominantly to South Asian clientele (Kohane, 2005; ICICI Bank, 2009). The bank is the second largest in India with all of its Ontario branches (Brampton, Mississauga, Scarborough, Downtown Toronto, Gerrard Street East, Don Valley Parkway, and Gore Road) located in the GTA; these branches correspond with areas that have been associated with South Asian presence. The financial institution's Canadian branches specialize in money transfers and bank loans to India, Bangladesh and Sri Lanka (Thibodeau, 2007). With strategies such as staffing branches with representatives that "reflect the community in which they're located" (Kohane, 2005, para 16) and its admittedly aggressive growth strategy in Canada, the presence of the ICICI Bank in the India Bazaar is no mistake. In addition to establishing branches that reflect its South Asian identity, the institution's main goal 
is to "position ourselves not just as an Indian financial institution but as a premier South Asian bank in the country" (Kohane, 2005, para 20).

\section{India Bazaar Challenges}

There are a number of circumstances that have negatively impacted the prosperity of the India Bazaar. Most notably, the lack of institutional completeness within the Toronto South Asian community has had the most influential impact (Marger \& Hoffman, 1992; Qadeer, 1999; Oliveira, 2000). This outcome is partially symptomatic of the individualistic style of South Asian entrepreneurs who tend to be reluctant to accept or receive external support from bureaucratic agencies and likely because of weak ethnic solidarity (Barrett, Jones \& McEvoy, 2001). Additional structural policy changes that were enforced by the state, such as city deregulations on store hours, interfere with the business strategies of ethnic entrepreneurs forcing them to compete with corporate counterparts, eliminating ethnic entrepreneurial niches of opening for long hours. Also, changes in employment policy addressing the increase of minimum wage increases labour costs and decreases profit for small ethnic enterprises (Barrett, Jones \& McEvoy, 2001). Securitization of the U.S/Canada border post-9/11 has also made it difficult for tourists that the India Bazaar depends on in the summer months to visit the area. At the neighbourhood level, complaints from residents in the area regard high traffic, loitering, smells and parking, which has caused an element of tension between residents and area merchants (Oliveira, 2000; Brouse, 2005; Leroy, 1978; Bauder \& Suorineni, 2010). 


\section{Chapter 4: Research Design}

\section{Scope}

The study focused on ethnic enterprises surrounding Gerrard Street East and Coxwell Avenue in Toronto, Ontario, Canada, which is where the Gerrard India Bazaar is located. Surrounding areas of the India Bazaar from Gerrard Street East \& Greenwood Avenue to Gerrard street East \& Coxwell Avenue and Queen Street East \& Greenwood Avenue and Queen Street East \& Coxwell Avenue were included in the research to supply the residential context. There was no in-depth analysis of other emerging South Asian commercial marketplaces in the Greater Toronto Area, except as a point of comparison, All information-gathering techniques were strictly archival-based.

\section{Design}

This qualitative research utilized a case study design in the context of a theoretically informed analysis of the phenomenon of the India Bazaar's commercial identity. The study attempts to gain insights into the strategies and barriers that the ethnic entrepreneurs of the India Bazaar encountered by employing the use of archival materials such as newspapers, business directories and government census information that document the commercial identity and residential history of the Gerrard/Coxwell area. The research design for this study is a single case study, which is focusing on an issue and selection of a bounded case to illustrate the issue (Stake, 1995). The purpose of a case study is to examine a particular case in an in-depth manner and from within its geographical setting in order to understand its complexities and context (Yin, 2008). The use of the case study has been an accepted research approach that is utilized to 
understand a common social phenomenon (Yin, 2003). The case study approach is effective in answering questions of the "how" and "why" involved in a set of processes to provide a rich perspective with regard to a number of complicated processes that may be occurring (Yin, 2008). Thus, the single case study facilitates an in-depth analysis of a particular phenomenon (Ruddin, 2006), such as the atypical development of the Gerrard/Coxwell's ethnic economy. The benefit of a single-case study is that it can function as a critical test of significant theories (Yin, 2008; Wiebe \& Durepos, 2009); Gillham, 2000).

\section{Data Collection}

Research was restricted to documents and archival material that pertain to the commercial identity of the India Bazaar. The limitation of using such data is that one has to consider variance in the degree of bias and the differences among documents (e.g. census tract vs. newspaper article) regarding their intended audience, which the researcher addressed when appropriate. Issues of validity were addressed by recording archival information as accurately as possible by minimally paraphrasing information found from newspaper articles and recording information as it was exactly stated into notes and photocopying as well as referencing as accurately as possible each archival record and document used (Walcott, 1990; Creswell, 2009). This method of analysis has been suggested by Yin (2003) to facilitate the formulation and construction of valid conclusions when utilizing qualitative research methods such as the single case study that have no standardized format for presenting research. The primary ethical consideration that pertains to the archival and document research methods is the respect for research sites. That is, to leave places that provide archival, document information undisturbed, and in the same state as it 
previously was after research has been conducted and to treat fragile old archival materials, such as photos, maps, and newspapers with care (Creswell, 2009), in addition to accurately representing information from events that occurred in the past, without incriminating others. The single case study analysis relies on three major sources of information all of which are from secondary sources. Samples will consist of information from the MIGHTS directory for the years of $1971,1982,1991,1996,1999$ and 2009, with a specific focus on areas in the Gerrard/Coxwell region (MIGHT's Business Directories, $1971 ; 1982 ; 1991 ; 1996 ; 1999 ; 2009)$. This will be used to trace the growth of the India Bazaar. The second source was census tract data for the Gerrard/Coxwell to Gerrard/Greenwood and Queen/Greenwood and Queen/Coxwell regions for the years of $1971,1976,1986,1996$ and 2006 with specific focus on immigration and visible minority population to trace the evolution of ethnic population in the area. Census Tract 26 and Census Tract 76 from the Statistics Canada Census were selected to provide the residential context of the India Bazaar, both census tracts represents the surrounding areas of the Gerrard India Bazaar. Lastly, newspaper articles discussing the commercial activity of the India Bazaar were sampled to gain familiarity with the commercial activity in the area and common themes that may arise. 


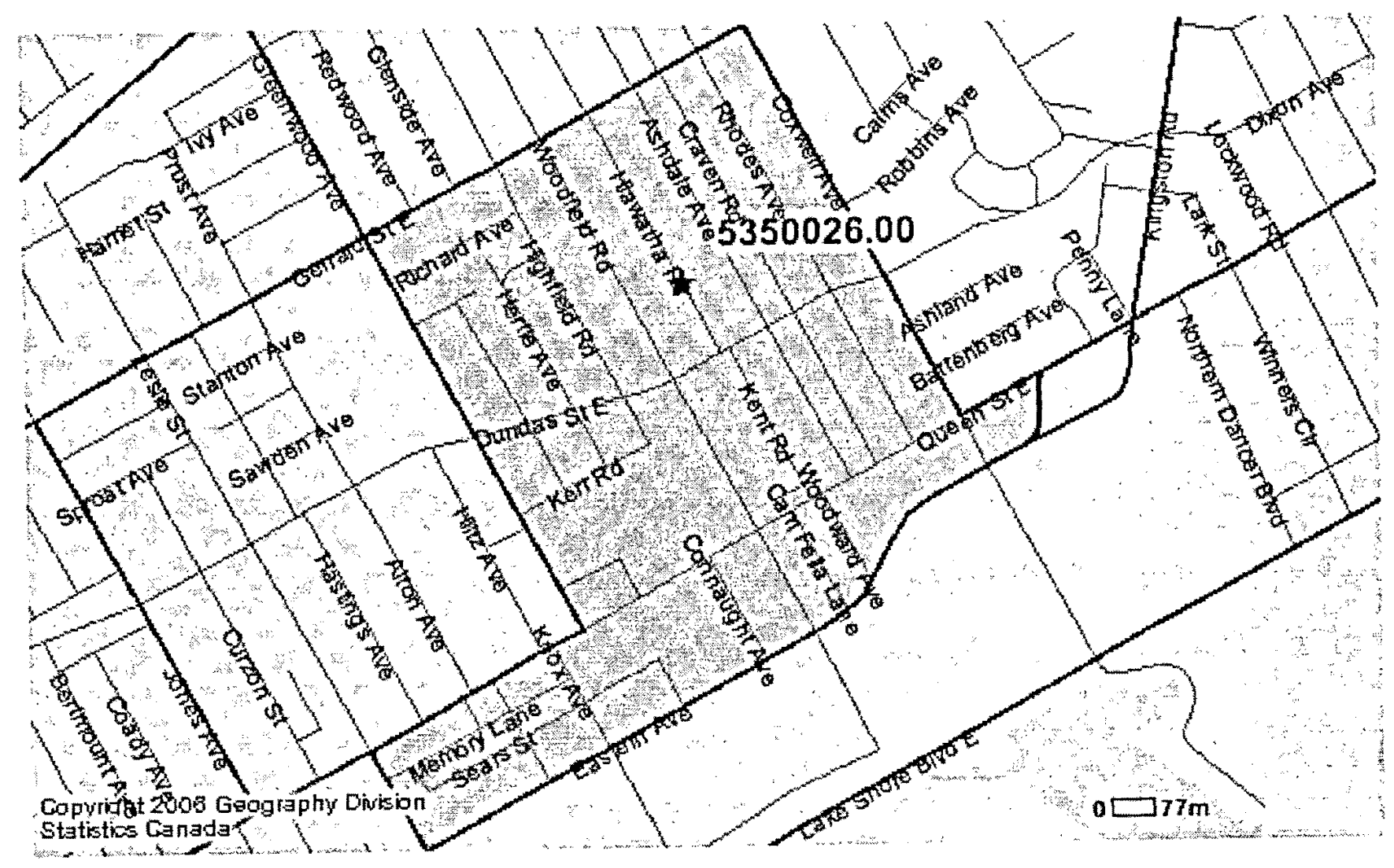

Figure 1: Census Tract (CT) 0026.00 profile for Toronto (CMA) 


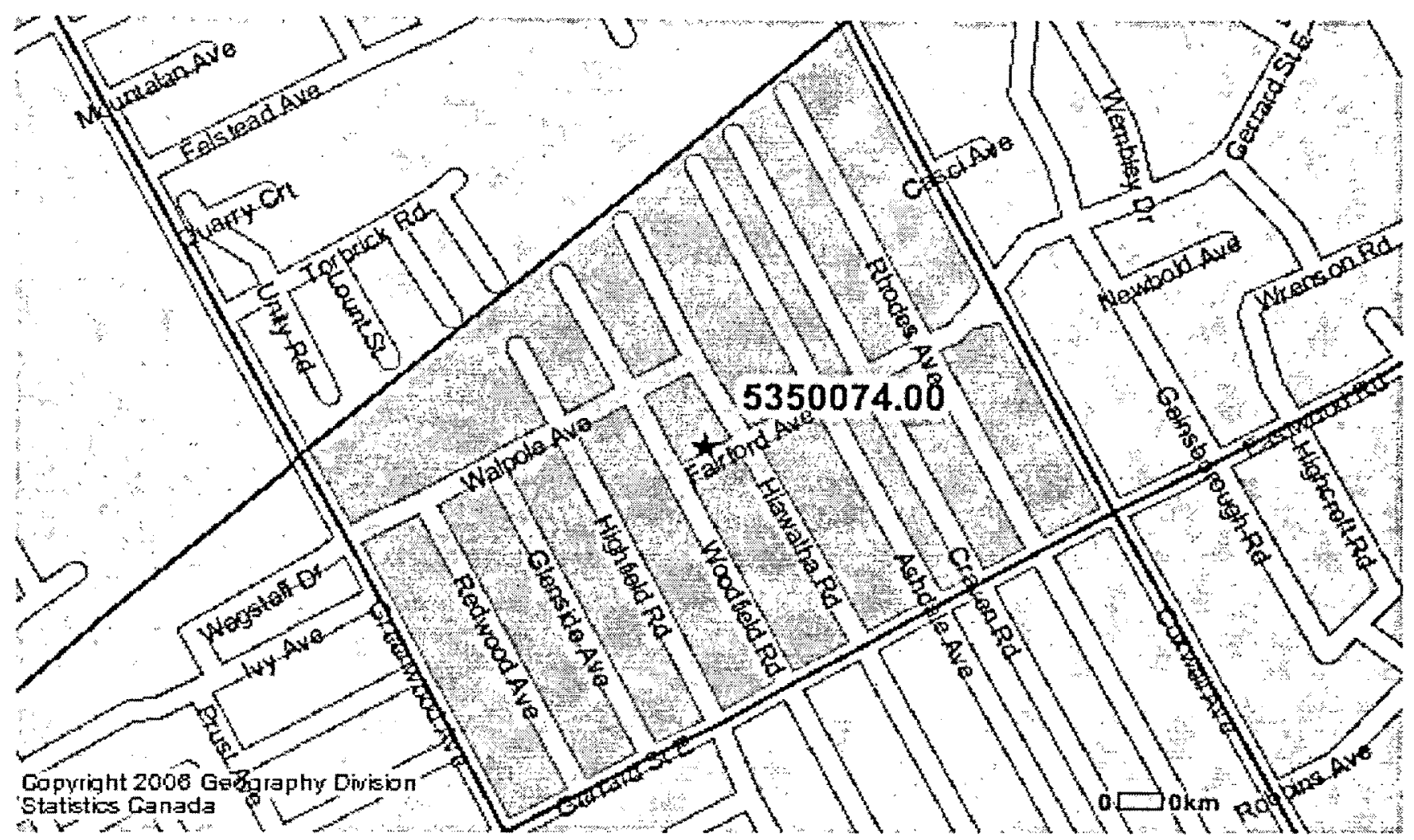

Figure 2: Census Tract (CT) 0074.00 profile for Toronto (CMA)

\section{Research Questions}

The research questions for the study encompass the commercial development of the Gerrard/Coxwell region into a South Asian marketplace from 1974 until 2010 based on the India Bazaar's development that contradicts prevalent theories on ethnic commercial development:

1) Why did the Gerrard India Bazaar emerge in an area that has no corresponding residential population, although the literature consistently assumes that residential and business enclaves coexist at the same location?

2) What factors were involved with the India Bazaar's theoretically incongruent development as an ethnic commercial space? How did those factors contribute to its longevity as a South Asian marketplace? 


\section{Chapter 5: Results}

\section{India Bazaar Commercial Identity}

In its August 20, 2005 issue, the Toronto Star published an article discussing the progression of the India Bazaar from the perspective of its South Asian entrepreneurs. The article cited location, ambience and the diversity as what set Little India apart from emerging South Asian suburban malls. With regards to location, the India Bazaar is easily reached by taking the 506 Streetcar and it is also close to the Gardiner Expressway for those who wish to drive there. In contrast, the "905-area" malls are said to consist mainly of Punjabi-style stores and restaurant and do not offer the constellation of South Asian stores, owned and operated by those of different South Asian backgrounds. For example, stores in the Bazaar are run by East Indians, Sri Lankans, Bangladeshis and Pakistanis, offering a variety of food choices that range from North Indian Tikka to South Indian dosa. According to one shop owner, the diversity and ambience of the India Bazaar is especially important for those in the South Asian community who have discriminating tastes and can tell the difference between what regions their merchandise or food is coming from. In addition to the sights, smells and atmosphere that conjure up the image of being "back home". The suburban malls have been criticized to only offer select items to its South Asian patrons, operating more like a 'corner store' as opposed to the choice and variety the Bazaar has. Indeed, Inder Jandoo states that "...no one from Scarborough is going to drive all the way down here just to shop or eat bhel, like they do here". Jandoo, is a shop owner who opened Sanu Saree Palace in 1979, which has been expanded into a 6000 square foot, three floor store. According to the article, Jandoo and other established merchants in the Bazaar did previously venture to the suburbs to open stores in addition to the ones they operated in the Bazaar. However, their suburban counterparts could not match the success of their stores in the 
Bazaar. According to one restaurant owner, "We could pack up and go to Mississauga where there's more space and more South Asians and recreate the whole thing but we're not moving...the Gerrard India Bazaar is world famous and has limitless potential". Similarly, Al Noor, owner of Lahore Tikka Restaurant expanded his 1400 square foot restaurant into a 10,000 square foot space in preparation for the future of his business and to accommodate the demand his well-known restaurant generates. Subbu Chintaluri, the Gerrard India Bazaar BIA coordinator, reports that the styles of the shops of the India Bazaar are mostly "mom and pop" shops which run with the help of family contributions. According to Chintaluri the area is, “... a compact one stop shop for jewelry, grocery, fabric, saris, anything and everything South Asian". He adds, that "being non partisan is a key to maintaining harmony among the Bazaar's diverse merchants". The area has proved to be a successful avenue of economic mobility for some owners, who now own the buildings they used to rent. The article explains that while the South Asian supermalls that have opened in Brampton and Mississauga in accordance with the large South Asian presence there, the India Bazaar has the local and world-renowned distinction that the supermalls do not have and it continues to expand and thrive because of its broadened appeal to the mainstream while conserving its traditional features to maintain its South Asian customers and rebranding itself as a tourist destination. Tourists are said to come from all over Canada, and from other parts of the world such as, Germany and other parts of Europe. However, the article indicates a slowdown of tourism to the area as a result of $9 / 11$, "because of tightened border checks and is only starting to pick up again". That said, the area is reported to be at its busiest between the months of March and October, with an average of 150,000 visitors over the weekends, and attracts many more people because of its annual street festival modeled after the Greektown's Taste of Danforth. 
Therefore, the article demonstrates that the local identity of the Gerrard Coxwell area as a South Asian business district has become entrenched, due the authenticity it exudes as a South Asian marketplace. Furthermore, the India Bazaar's identity as an authentic South Asian marketplace has facilitated its success above other emerging South Asian business districts in the suburbs.

\section{Developments of the India Bazaar}

In its July $20^{\text {th }} 1978$ issue, Ward 8 News, the community newspaper published an article documenting the many problems the India Bazaar was encountering. Leroy (1978) reveals a conversation he had with an unnamed frustrated business owner concerning the activity surrounding the India Bazaar. In his response to the business owner, Leroy (1978) offers a conviction of hopefulness and patience regarding the potential growth of the area, "I pointed to the East Indian merchants shops that line both sides of Gerrard Street East from Woodfield Road to Coxwell...one must consider the relative newness of these merchants. Some have been visible in the area much longer than others, but they continue to build, buy and increase the size of their establishments in this so-called, "tough area"”.

Leroy (1978) was correct to hint at the sustainability of the India Bazaar because in 1980, two years after his article was published, two articles, one from Ward 8 News and the other from the Toronto Star discussed the opening of an East Indian mall in the area. According to the Toronto Star (1980), the new mall on Gerrard St East and Greenwood Ave named the Amitabh Mall was going to be the first of its kind in North America, created to cater mainly to East Indian tastes, "selling exclusively East Indian products". The article lists three investors that owned the mall, Dr. Hirsch Rastogi, a South Asian, gastroenologist who ran a practice in Hamilton, Bernie Waldman, a Jewish businessman and Harsukh Ganatra. According to Harsukh Ganatra, the mall 
consisted of 16 stores that were intended to meet the demands of the "growing East Indian community along Gerrard between Greenwood and Coxwell".

The Toronto Star (1980) article notes that the merchants running businesses in the mall came from a range of South Asian backgrounds. The article depicted the mall as being successful, detailing one merchant's account of selling a family from Detroit $\$ 700$ worth of food, intended for a wedding reception. The Ward 8 News (1980) account of the mall provided more details such as the origin of the name of the mall, named after Amitabh Bachan a famous movie actor. The article mentioned the types of stores in the mall included discount store, electronic shops and many take-out food stores. That said, the opening of the mall was compared to an established East Indian Bazaar on Donland's Ave near O'Connor, that was said to be comparable to 'any street in any city in India" (Ward 8 News, 1980). Nonetheless, Yelaja (2005) revealed that the Amitabh mall quietly shut down months after it opened because of low sales.

That being said, an article was published two years later about the opening of another East Indian mall. The article discusses the new ownership, renovation and redesigning of the Eastwood Theater, previously an East Indian cinema (Paradkar, 2000) to include 8 commercial units that would provide services and employment. Bruzual (1982) reveals that the restructured theatre was involved in further talks to be developed into a cinema that would provide a wider range of South Asian content, "...The theater was in talks to provide movies for other cultural backgrounds, especially Indo-Asian cultures - to further enhance Canadian awareness of immigrant culture". According to the article (Bruzual, 1982) the reasoning behind the restructuring of the cinema was because of the area's 'unique' and 'diasporic international appeal' that "smacked of cultural expressions". Eventually, in the late 90 s advancements in video technology in the home and the screening of Bollywood movies in the suburbs would 
cause the Eastwood Theater to stop operating as an East Indian cinema (Hutsul, 2004). The initial articles demonstrate the growth of the India Bazaar in matter of a few years into a wellrecognized South Asian business district that was quickly being expanded, with the inclusion of two East Indian malls. While the success of those malls was marginal, it indicated South Asian entrepreneurs were confident enough in the area to invest in expensive commercial endeavors, despite its infancy at the time.

Also in 1982, the Gerrard India Bazaar News newsletter was circulated to local entrepreneurs discussing 'advertising through the media'. The newsletter was generated and issued by the Gerrard India Bazaar BIA, as a formal introduction to the community of merchants, "On July 8, 1982 the city of Toronto approved an area between Craven Road and Woodfield as a business improvement area known as Gerrard India Bazaar. The city of Toronto also endorsed a budget of $\$ 10,000$ for the Gerard India bazaar..." According to the newsletter, the initial budget was appropriated to improve street lighting of the area and the use of an area school to provide additional parking for shoppers. The newsletter also described specific ways in which the entrepreneurs of the India Bazaar were to conduct their matters of advertising, in order to address the area's rebranding:

Now that the India bazaar has legal recognition let your advertisements end with the following words:

Ad Message, name of advertiser, address....Gerard Street East India Bazaar. A constant ringing of the name India Bazaar in the ears of customers will provide a solid base and goodwill for India bazaar. Don't forget, every visitor is your potential customer, regardless of whose advertisement he/she listens to. Please amend the text of your 
written, verbal or T.V. ads to end the advertisement with Gerrard Street East in the India Bazaar (Gerrard India Bazaar News, 1982).

The article demonstrates, the use of ethnic strategy (Qadeer, 1999) to tap into own group structures and characteristics, the only difference being that instead of an ethnic community putting forth the strategies, it is the ethnic commercial community. Furthermore, the recognition of the India Bazaar by the municipality of Toronto as a legitimate South Asian commercial space that needed support was evidence that the Bazaar had become embedded in the Gerrard Coxwell area.

Fifteen years later, after the first Gerrard India Bazaar newsletter was issued, an article was published by the Toronto Star (Acarya, 1997) which focused on the authenticity of the India Bazaar and its familiarity to shoppers. The article explained that generational changes in demand from shoppers did slow down its profitability. For the most part, the second generation of South Asians in the community were not particularly interested in keeping up with traditional cuisine and related commodities. However, the article hinted at a new generation of merchants in the area that were not South Asian and establishing smaller 'sidewalk' businesses. For instance, a second generation Afghani was reported to use his earnings from selling barbecued corn on the cob on an India Bazaar sidewalk with his siblings to pay off his York University school tuition. While the decreased demand from second generations South Asians did slow down business in the area, the weekends still brought shoppers filling up the small grocery stores and "spilling into the sidewalk". According to Acarya (1997), the Gerrard India Bazaar BIA was already in the process of addressing the decrease of generational demand by pursuing the area's "official recognition as a metro tourist destination". Similarly, in August 20, 2005, the Toronto Star published another article on the India Bazaar that addressed the generational change of 
merchants in the area, "Trish Mahtani represents Little India's second generation of merchants. Last August, she opened 'Rang', a home décor shop right across the street from her parents' sari store NuCreation Fashion, where she used to help out after school". The article also revealed that some of the established entrepreneurs in the area were opening multiple stores in the area, "Another firm believer in the viability of the strip, Multani bought out Milan's-12,000 square foot department store selling everything from Ganesh statues to glass bangles-in 1998. It's run by his wife and just down the street from his restaurant." Lastly, Yelaja (2005) reports in the article of worldwide academic attention focused on the India Bazaar as an exemplary model for emerging ethnic economies evidenced by a group of people from a university in Germany studying the area for that purpose.

Table 1: Businesses on Gerrard Street East and Coxwell Ave Area

\begin{tabular}{|c|c|c|c|c|c|c|c|c|c|c|}
\hline \multirow[b]{2}{*}{ Year } & \multicolumn{9}{|c|}{ Types of Businesses } & \multirow[b]{2}{*}{ Total } \\
\hline & $\begin{array}{l}\text { Grocery and Food } \\
\text { Related Stores }\end{array}$ & Restaurants & Hair \& Beauty & $\begin{array}{l}\text { Clothing and } \\
\text { Fabric (Retail) }\end{array}$ & $\begin{array}{c}\text { Jewellery and } \\
\text { Crafts }\end{array}$ & $\begin{array}{c}\text { Electronics, } \\
\text { Video \& } \\
\text { Entertainment }\end{array}$ & $\begin{array}{c}\text { Home \& } \\
\text { Décor }\end{array}$ & Services & Miscellaneous & \\
\hline 1971 & & 4 & 4 & 3 & & 1 & 2 & 14 & 7 & 44 \\
\hline 1982 & & 6 & & 5 & 40 & 4 & & 1 & 4 & 29 \\
\hline 1991 & & 7 & & $m_{m}$ & 3 & 3 & 1 & 2 & & 19 \\
\hline 1996 & & 18 & & 30 & Ther & 5 & & & & 62 \\
\hline 1999 & 12 & 20 & 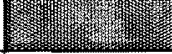 & 2 & 12 & 7 & & 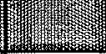 & 2 & 55 \\
\hline 2009 & $5 \%$ & 12 & 1 & $16 /$ & 7 & 3 & & 2 & 3 & 49 \\
\hline
\end{tabular}

Source: MIGHTS Business Directories, Toronto, Ontario; 1971, 1982, 1991, 1996, 1999, 2009

Table 1 provides a chronological account of the types of businesses that have operated in the area, beginning with 1971 when there was no presence of South Asian businesses. The table reveals that over the years, some types of businesses have maintained a consistent presence (i.e. 
Grocery and food related stores, restaurants, electronics, video \& entertainment and clothing \& fabric (retail)), while the presence of other types of businesses declined as the South Asian commercial presence in the area became more pronounced (i.e. hair and beauty, home \& décor). Next, the table shows that the most number of businesses in the area have been in recent years, in $1996,1999,2009$ with 62,55 and 49 stores respectively. Also, comparing 1971, when there were no South Asian businesses in the area to 2009, when all the businesses in the area are South Asian the table shows that there is a matching spread of types of businesses in the Gerrard Coxwell area. That said, the general increase of businesses in the area demonstrates that the South Asian businesses in the area have positively affected the local economy of the area in terms of revitalization (Brouse, 2005; Oliveira, 2000; Bauder \& Suorineni, 2010). The table verifies the growth of South Asian business over the years without a corresponding residential identity. The $66 \%$ decrease in businesses in the area from 1971 to 1982 , reflects the vacancy of businesses of the previous commercial ethnic cohort and the entrance of South Asian businesses, since archival information shows that by 1982 , the Gerrard Coxwell area was considered a South Asian commercial district (Bruzual, 1982; Gerrard India Bazaar News, 1982; Brouse, 2005). In addition, the matching spread of types of businesses of 1971 and 2009 reflects the ethnic strategy of appealing to the mainstream market with the diversity of types of businesses in the area (Hutsul, 2004; Brouse, 2005).

\section{Image of the India Bazaar to the Local and International South Asian Community}

Recent articles published about the India Bazaar discuss its viability within the local community of South Asians. One publication described the attendance of a Pakistan Independence Day celebration at the India Bazaar as the most "dignified"," successful" and 
"well attended" in the GTA as a result of the India Bazaar's reputation in the South Asian subcontinent. Not only was the celebration attended by NDP leader Jack Layton, but also included the attendance of a well-known South Asian entertainer and Pakistani heads of state (i.e., Minister Zafarullah Khan Jamali, Pakistan President General Pervez Musharraf) (Fraser, 2003). Subsequently in 2004, a Toronto Star article evaluated the advent of emerging South Asian commercial spaces in the suburbs of Toronto (i.e. Rexdale, Brampton, Malton) in comparison to the India Bazaar, in that they were starting to offer the same goods and services that were previously only available in the Bazaar (Hutsul, 2004). These competitors were also providing conveniences that the India Bazaar traditionally had problems with (i.e. "increased parking", "less cramped") (Brouse, 2005). Consequently, the presence of suburban South Asians in the area is visibly decreasing, "...the people who came to lick kulfi and chew paan, buy Bollywood videos and Islamic books, or get outfitted in bridal saris and 22 karat gold wedding jewelry lived in Markham, Mississauga or Malton" (Brouse, 2005). While some India Bazaar merchants acknowledged the decrease of business from South Asians in general, "the South Asian community in the U.S, used to arrive by the busloads... we even had people driving from Buffalo for lunch". That said, "suppliers in Bangalore and Delhi know all about Gerrard" (Brouse, 2005). Other India Bazaar merchants credit the India Bazaar for revitalizing the Gerrard/Coxwell area and pioneering South Asian commercial (spatial) activity in Toronto, "...we have lost business to the commercial areas in the suburbs, but in a way it helps us...it used to be a slum area and now it's one of the most famous areas in the city" (Hutsul, 2004). Although, recent articles that refer to the position of the India Bazaar within the GTA South Asian community state the emergence of better and closer South Asian centers in the suburbs, 
they highlight an understanding within the community that the India Bazaar is a well-recognized, renowned prototype of South Asian commercial activity that can be imitated but not duplicated.

\section{Image to the Mainstream GTA Market}

Even in the early days of the India Bazaar, articles written about the area revealed that the area was known to be frequented by Torontonians who were looking for a "taste of India". Indeed, the area was known as a popular destination for Sunday walks (Toronto Star, 1977). More recent articles on the Bazaar feature the India Bazaar as a place where one can take a journey to the subcontinent without leaving the city. Bain (2003) described the area as an epicurean hotspot for South Asian cuisine, imploring to readers to attend areas 'Taste of India' food festival. The publication, India Abroad (2004) described in its article the channeling of the curiosities of the mainstream by merchants of the India Bazaar as a way to increase profits:

The South Asian community comes in busloads to the market, where they can find almost all goods, including jewelry, clothes, groceries and books from their homeland. But the competition from other similar markets which have sprung up across the city has led the market to change its strategy to attract mainstream customers (Nain, 2004).

The articles demonstrate that the merchants of the India Bazaar have become responsive to the strategy of marketing to the mainstream. 


\section{Challenges to the India Bazaar}

Recent and past articles on the India Bazaar have identified a decrease of coethnic clientele as a challenge to the India Bazaar. Prior challenges revolved around its physical atmosphere and structural issues which made the establishment of the Gerrard India Bazaar BIA, a necessary intuitional asset. According to Snider (1984), the government of Ontario authorized the concept of Business Improvement Areas to help commercially revitalize deteriorating neighborhoods. A B.I.A consisted of a business community applying and receiving approval by their municipal council for designation. The B.I.A would generate its funding from tax levies applied to local businesses, where money generated would be used for neighborhood beautification and promotional programs. Accordingly, the Gerrard India Bazaar was officially established on July 8, 1982 (Gerrard India Bazaar News, 1982). Still, two years later, the Gerrard India Bazaar was known for having "cracked sidewalks, peeling paint, litter, ripped awnings and bad lighting" so much so that, "local investment dropped" and "level of pride in the area suffered" (Snider, 1984). Snider was not optimistic, when he commented, "physical and emotional symptoms can spell out the death of the community" (Snider, 1984). Ten years later, a February 17,1984 , a Toronto Star article verified that the area was still troubled and beginning to affect nearby ethnic commercial spaces, "Business failure in Gerrard and Coxwell is affecting metro-Korean community's businesses in the area" (Parent, 1984). More recent challenges not only include decreased interest from generational differences for impacting the growth of the India Bazaar but also the dramatic decrease in tourists from the United States to the area $(70 \%$ drop since 2005) due to SARS, dropping U.S currency exchange and September 11 (Brouse, 2005). For instance, Brouse (2005) illustrates "...crossing the border wearing a turban and carrying a bag of chickpea flour can be a recipe for harassment". The articles demonstrate the 
physical consequences that accompanied the commercial succession of the area previous ethnic commercial identity inhabitants during its infancy. Though the deteriorating condition of the area was effectively addressed by the inception of the Gerrard India Bazaar BIA, it underwent a 10year period of recession that threatened its existence within the area. That said, its longer lasting subsequent challenges involved external situations such as the outbreak of SARS, the U.S economy and the cascading effects of global terrorism and the subsequent "war on terrorism".

\section{Gerrard Street East and Coxwell Avenue: Residential History and Development}

According to Brouse (2005) the earlier residents at the turn of the century in the area were Greek and Italian construction workers and Anglo-Saxons who worked at a nearby Colgate and Wrigley factory. East Indian settlement occurred at the furthermost Eastem boundary of Gerrard/Coxwell. That said, the South Asian commercial presence in the area was able to elevate its working class reputation in addition to a demand for cheaper housing in contrast to rising housing prices in the nearby Cabbagetown area and neighbourhoods west of Yonge Street (Stein, 1984). Presently, the demography of the neighborhood is in stark contrast to its earlier composition (Table 2, Table 3, Table 4, Table 5), where the residents are predominately from professional background who have taken to remodeling the rundown century row houses and semi-detached houses that line the streets in the area.

Table 2 provides demographic information regarding the population, mobility status and home language of individuals residing in the areas surrounding the India Bazaar in 1976. Mobility status "refers to the the status of a person with regard to the place of residence on the reference day in relation to the place of residence on the same date one year earlier" (Statistics Canada, 2010 , para 4). The mobility status was used to obtain a reference of immigrants in the area, since 
there was no data provided about immigration in the 1976 Census tract. The same rationale was used regarding home language, which provided a general concept of nationalities that resided in the area at the time. The table shows that fewer than $10 \%$ of residents in the Gerrard Coxwell region had a mobility status that was from outside of Canada and that most of the residents in the area were English speakers. The information from the 1976 census tract confirms that there was an absence of ethnic minorities in the residential context at the time Gian Naaz had purchased the Eastwood Theatre to display South Asian films (Paradkar, 2000).

Table 3 provides demographic information regarding the population, home language, ethnic origin and immigrant population of individuals residing in the areas surrounding the India Bazaar in 1986. The table shows that the language spoken at home was predominately English, however Chinese was spoken by residents in census tract $26(11.4)$ and census tract $74(16.3)$ indicating that the ethnic composition of residents in the area was becoming more diversified since the 1976 census, especially with regards to ethnic presence. Correspondingly, the ethnic origin and immigrant section of the census tracts show that there was a marginal South Asian residential presence in census tract 26 and census tract 74 (1.1 and 2.9, respectively).

Table 4 provides demographic information regarding the population, home language, ethnic origin, and immigrant population of individuals residing in the areas surrounding the India Bazaar in 1996. The table shows that in the 10 years between the 1986 and 1996, the amount and background of individuals residing in the area had transformed into a more varied. For example, the table shows that Chinese being spoken at home grew from $11.4 \%$ vs. $16.3 \%$ in census tract 26 and census tract 74 , respectively in 1986 to $24.0 \%$ and $24.7 \%$ in census tract 26 and census tract 74 respectively in 1996 , an increase of $12.6 \%$ and $8.4 \%$ in census tract 26 and census tract 
74 , respectively. Specifically, Punjabi, a South Asian dialect was also spoken at home $1.4 \%$ in census tract 26 and $1.5 \%$ in census tract 74 . The residential South Asian ethnic origin population in the areas grew from $1.1 \%$ vs. $2.9 \%$ in census tract 26 and census tract 74 , respectively in 1986 to $6.8 \%$ vs. $6.5 \%$ in census tract 26 and census tract 74 , respectively in 1996 , an increase of $5.7 \%$ vs. $4.0 \%$ in census tract 26 and census tract 74 , respectively. In addition to other nonCaucasian ethnicities in the area such as Portuguese ( $2.2 \%$ only in census tract 26$)$, Jamaican (1.1\% vs. $4.2 \%)$ and Filipino ( $2.1 \%$ vs. $2.8 \% \mathrm{i}) \mathrm{n}$ census tract 26 and census tract 74 , respectively. Furthermore, the immigrant population grew from $32.1 \%$ vs. $39.8 \%$ for census tract 26 and census tract 74 in 1986 to $41.7 \%$ vs. $44.2 \%$ for census tract 26 and census tract 74 in 1996.

Table 5 provides the demographic information regarding the population, home language, immigrant status of individuals residing in the areas surrounding the India Bazaar in 2006. Table 5 shows that the immigrant population of census tract 26 and census tract 74 are $36.2 \%$ and $40.6 \%$, respectively indicating a continued increase of immigrants to the area (5.5\% vs. $3.6 \%$ from 1996).

Tables 2, 3, 4 and 5 outline a general increase of ethnic minorities in the areas surrounding the India Bazaar over the years, particularly a growing residential presence of South Asians beginning in 1986. This indicates the South Asian commercial identity of the India Bazaar in the Gerrard Coxwell area may have attracted a noticeable residential presence of South Asians to the area. 
Table 2: 1976 Selected Census Tract Data for North and South Gerrard Street East and Coxwell Ave

\begin{tabular}{|c|c|c|}
\hline & Census Tract 26 & Census Tract 74 \\
\hline \multicolumn{3}{|l|}{ Population } \\
\hline Population in 1976 & 8276 & 3970 \\
\hline Population in 1971 & 7130 & 4635 \\
\hline $\begin{array}{l}1971-1976 \text { Population in } \\
\text { change }(\%)\end{array}$ & 16.1 & -14.3 \\
\hline \multicolumn{3}{|l|}{ Mobility Status ( $\%$ of CT) } \\
\hline From Outside of Canada & 505 & 335 \\
\hline$\%$ of Census Tract & 6.1 & 8.4 \\
\hline \multicolumn{3}{|l|}{$\begin{array}{l}\text { Home Language ( } \% \text { of CT) } \\
(1976)\end{array}$} \\
\hline English & 63.6 & 66.9 \\
\hline French & 1.9 & 2.1 \\
\hline German & 1.4 & 1.4 \\
\hline Italian & 1.6 & 4.7 \\
\hline Ukrainian & 0.8 & 1.0 \\
\hline Other & 1.8 & 20.4 \\
\hline
\end{tabular}

Table 3: 1986 Selected Census Tract Data for North and South Gerrard Street East and Coxwell Ave

\begin{tabular}{|l|r|r|}
\hline & Census Tract 26 & Census Tract 74 \\
\hline Population & & \\
\hline Population in 1986 & 6642 & 3660 \\
\hline Population in 1981 & 6531 & 3476 \\
\hline $1981-1986$ Population & & \\
Change in \% & 1.7 & \\
& & \\
\hline By Home Language (\% of & & 5.3 \\
CT) & 75.1 & \\
\hline English & 0.8 & 65.0 \\
\hline French & 16.9 & 0.5 \\
\hline Non-official languages & 0.7 & 27.0 \\
\hline Italian & 11.4 & 1.1 \\
\hline Chinese & 0.8 & 16.3 \\
\hline Portuguese & 0.8 & $\mathrm{n} / \mathbf{a}$ \\
\hline Greek & & 1.0 \\
\hline
\end{tabular}




\begin{tabular}{|c|c|c|}
\hline Spanish & 0.2 & 0.5 \\
\hline Other languages & 3.2 & 8.1 \\
\hline Multiple responses & 7.0 & 7.4 \\
\hline \multicolumn{3}{|l|}{ By Ethnic Origin( $\%$ of CT) } \\
\hline British & 33.5 & 29.5 \\
\hline French & 2.5 & 2.7 \\
\hline Italian & 2.0 & 2.2 \\
\hline Chinese & 14.8 & 16.9 \\
\hline Jewish & 0.5 & 0.3 \\
\hline South Asian & 1.1 & 2.9 \\
\hline Portuguese & 1.2 & 0.5 \\
\hline Other single origins & 15.4 & 18.7 \\
\hline Multiple origins & 29.0 & 26.0 \\
\hline \multicolumn{3}{|l|}{ Immigrant Status } \\
\hline Non-immigrant population & 67.5 & 60.0 \\
\hline Immigrant population & 32.1 & 39.8 \\
\hline
\end{tabular}

Source: Statistics Canada, Census 1986

Table 4: 1996 Selected Census Tract Data for North and South Gerrard Street East and Coxwell Avenue

\begin{tabular}{|l|r|r|}
\hline & Census Tract 26 & Census Tract 74 \\
\hline Population & 7174 & 4388 \\
\hline Population in 1996 & 6602 & 4154 \\
\hline Population in 1991 & 8.7 & 5.6 \\
\hline $\begin{array}{l}\text { 1986-1991 Population } \\
\text { change in \% }\end{array}$ & & \\
\hline $\begin{array}{l}\text { By Home Language( \% of } \\
\text { CT) }\end{array}$ & 66.1 & 63.0 \\
\hline English & 0.1 & 0.8 \\
\hline French & 31.0 & 32.0 \\
\hline Non-official languages & 20.2 & 20.9 \\
\hline Chinese & 0.6 & 0.6 \\
\hline Italian & 0.6 & $\mathrm{n} / \mathrm{a}$ \\
\hline Portuguese & $\mathrm{n} / \mathrm{a}$ & $\mathrm{n} / \mathrm{a}$ \\
\hline Polish & & \\
\hline
\end{tabular}




\begin{tabular}{|l|r|r|}
\hline Punjabi & 1.4 & 1.5 \\
\hline Other languages & 8.3 & 8.9 \\
\hline Multiple responses & 2.7 & 3.9 \\
\hline By Ethnic Origin(\% of CT) & & \\
\hline English & 20.8 & 19.6 \\
\hline Canadian & 16.0 & 17.7 \\
\hline Scottish & 12.2 & 14.0 \\
\hline Irish & 10.9 & 14.9 \\
\hline Italian & 2.6 & 3.8 \\
\hline South Asian origin & 6.8 & 6.5 \\
\hline Chinese & 26.0 & 26.3 \\
\hline French & 9.4 & 7.4 \\
\hline German & 4.3 & 6.0 \\
\hline Portuguese & 2.2 & $\mathrm{n} / \mathrm{a}$ \\
\hline Polish & 1.7 & 1.9 \\
\hline Jewish & 0.6 & $\mathrm{n} / \mathrm{a}$ \\
\hline Jamaican & 1.1 & 4.2 \\
\hline Filipino & 2.1 & 2.8 \\
\hline Ukrainian & 1.2 & 0.8 \\
\hline Immigrant Status & & 54.5 \\
\hline Non-immigrant population & 56.8 & 44.2 \\
\hline Immigrant population & 41.7 & \\
\hline
\end{tabular}

Source: Statistics Canada, Census 1996

Table 5: 2006 Selected Census Tract Data on North and South Gerrard Street East and Coxwell Ave

\begin{tabular}{|l|r|r|}
\hline & Census Tract 26 & Census Tract 74 \\
\hline Population & & \\
\hline Population in 2006 & 6505 & 4023 \\
\hline Population in 2001 & 6986 & 4504 \\
\hline $\begin{array}{l}1986-1991 \text { Population change } \\
\text { in \% }\end{array}$ & -6.9 & -10.7 \\
\hline $\begin{array}{l}\text { By Home Language (\% of } \\
\text { CT) }\end{array}$ & & \\
\hline English & 73.8 & 64.9 \\
\hline French & 0.2 & 0.2 \\
\hline Non-official language & 22.7 & 29.7 \\
\hline English and French & 0.2 & $\mathrm{n} / \mathrm{a}$ \\
\hline $\begin{array}{l}\text { English and non-official } \\
\text { language }\end{array}$ & 2.9 & 4.6 \\
\hline French and non-official & $\mathrm{n} / \mathbf{a}$ & $\mathrm{n} / \mathbf{a}$ \\
\hline
\end{tabular}




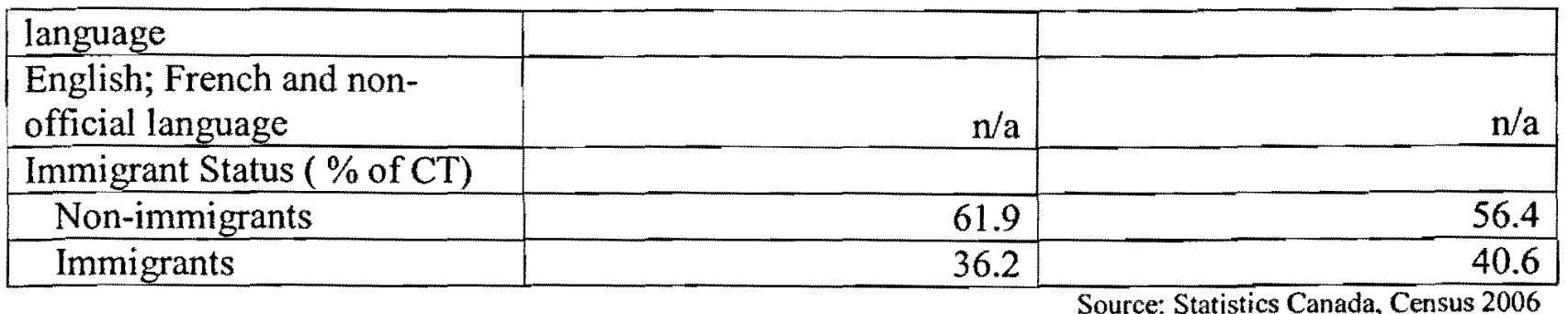

\section{Residential Impact on the India Bazaar}

Based on the archival research related to the residential impact of the Gerrard Coxwell area on the India Bazaar, it appears that there was always an underlying element of contention among local residents towards the Bazaar. According to Leroy (1978), the ongoing issues resulted in "hostility" from residents, especially regarding parking space. Subsequently, seven years later at a meeting organized by the Gerrard India Bazaar BIA, similar issues were addressed regarding parking space. According to the meeting notes, the lack of designated parking areas for customers created tension between residents and business-owners, resulting in a resident initiated petition being circulated around the neighborhood. Complaints from residents heightened when cars were being parked on lawns and driveways. A permanent solution that was quickly struck down by the city was the development of a defunct Esso Station in the area into a permanent parking area. However, the idea was not supported by the city because the property was too expensive (Heighton, 1985). Yelaja's (2005) article on the India Bazaar lends more insight into the nature of the conflicts between residents and merchants of the Bazaar in its earlier days. According to one merchant, his restaurant was regularly bombarded with eggs and his windows smashed, in addition to routinely receiving chants of 'Paki go home' on the street. That said, those who felt uncomfortable with the South Asian commercial presence in the neighborhood were thought to have eventually moved away. While there are still ongoing problems arising from lack of parking space, traffic congestion and littering in the area, residents 
who remain in the area or choose to live in the area tend to value the South Asian commercial presence. Indeed, one non-South Asian 13 year resident comments that while he appreciates the India Bazaar, he adds that, "I've known people who moved because of it". From the articles, it appears that the initial revolt of residents towards the India Bazaar has faded as the area's diversity increased. The 74 and 26 Census Tracts for 1976 , show that at the time of its development, the majority of residents in the area were English speaking (63.6 and 66.9) respectively. The 2006 Census Tract shows that while the proportion of non-visible minority residents has stayed relatively similar, the range and proportion of visible minorities living the area has increased. Correspondingly, Gerrard India Bazaar BIA coordinator Subbu Chintaluri reports that in addition to the celebration of South Asian religious festivals such as Muslim Eid, Hindu Diwali and Sikh Vaisakhi at the India Bazaar, Christmas is also celebrated because, “ ...we are in a neighborhood that is predominately Caucasian, so we feel we should be inclusive" (Yelaja, 2005). This demonstrates the there is a genuine effort on the part of the South Asian commercial community to accommodate the needs of its residential community.

\section{Adaptation of the India Bazaar}

An article from the community newspaper, Ward 8 News revealed concerns regarding the flow of patrons to the area, shortly after the emergence of the India Bazaar in the Gerrard/Coxwell area. Leroy (1978), the author of the article had suggested a BIA for the area be established to deal with the ongoing problems at the time. In the words of Leroy (1978):

I therefore suggested that the BIA should get together and organize a summer mall on

Gerrard running from Woodfield to Coxwell. There are two ways to approach the situation. One involves closing the route from the middle of June to the end of August. 
The only vehicles to pass would be streetcars and service trucks, both giving way to pedestrians. This could open opportunities for merchants to rent space to various craftsmen/artists to sell the result of their efforts. The second alternative is similar but would involve only a weekend closing of the strip

Accordingly, an article by the Toronto Star, in January 18, 2004 announced the India Bazaar as a permanent fixture in the neighborhood and a destination for all things South Asian. As reported by one India Bazaar merchant, the India Bazaar has thrived because of its ability to adapt. Which is becoming even more vital to the running of a business in the Bazaar "when a non-Indian comes to the store, the first thing we do is introduce and explain our products to them...the smarter store owners understand that they must do business with non-Indians. Otherwise the business will die" (Hutsul, 2004). Furthermore, the article indicates that elements of the South Asian culture, such as high profile Bollywood films and the "proliferation of the South Asian aesthetic" becoming mainstream has lent wider public interest in the Bazaar (Hutsul, 2004). Correspondingly, an earlier article from the Toronto Star (Capelaci, 1997) featured the India Bazaar as a destination area for East Indian fashions in response to fashion trends that involved the incorporation of East Indian traditional fashions and accessories with Western attire for women. That being the case, the Gerrard India Bazaar BIA's crucial role in the Bazaar's process of adaptation is specified in another article:

As part of their efforts to clean up the area and attract the mainstream and other ethnic groups to their stores, merchants recently installed 22 lampposts at the cost of $\$ 250,000$, Bajaj told India Abroad. Half the money came from the City of Toronto. The city collects about $\$ 150,000$ by way of taxes from the area. As part of the arrangement, that money is given to "our business area improvement board for upkeep of the area" says Bajaj. "It 
would be difficult for us to raise money directly from business people but they pay taxes to the city and happily... It gives that money back to us and that's how we keep the streets clean, provide parking facilities, and all other activities like celebrating Diwali, Eid and other religious festivals" (Nain, 2004).

Brouse's (2005) article on being a non-South Asian resident, living in the India Bazaar area also provides some insight into strategies the entrepreneurs are using to adapt to changes to their market. For instance, Balwant Jajj Singh singles himself out by being the only grocery store in the area that sells cross-cultural items, which has contributed to the success of his business. In Singh's words, "...people told me my store would never work... as the population grows and our second generation rise- -whether we like it or not the mainstream is going to be our main customer. Look at the UK, curry is the number one seller, it used to be fish and chips and a newspaper". Brouse (2005) adds that despite the No Frills in the vicinity locals and visitors come to his popular store whether they are in the mood for Oreo cookies or fried moong dal (Brouse, 2005). The articles illustrate strategies enacted by area institutions like Gerrard India Bazaar BIA and individual merchants to bridge the gap between their products and services to the mainstream. One possible explanation for the decrease of ethnic entrepreneurship could be attributed to the fact that recent South Asian immigrants are more educated and wealthier than previous cohorts, causing a shift away from the establishment of small business coupled by a divergence from settling within the metropolis and opting for suburban residential areas. This corresponds with the emerging South Asian malls in the GTA suburbs (i.e. the Tuxedo Court Complex at Markham Road and Highway 401 in Scarborough and the Ruby Queen Plaza at Airport and Derry Roads in Malton ) (Qadeer \& Kumar, 2003; Lo et al., 2004). 


\section{Chapter 6: Conclusion}

It has been stated that a clear picture of ethnic and immigrant self-employment can be obtained when the focus is shifted to an individual group (Hiebert, 2003). The goal of the present study was to examine the processes and challenges of the India Bazaar in relation to its incongruent residential identity. The India Bazaar was able to emerge without a corresponding South Asian enclave because the vacancy of businesses in the area came before residential vacancies that could facilitate South Asian settlement in the area. That said, there was no interest from the South Asian community at the time to settle in that area. However, South Asian entrepreneurial interest in the area, established by the opening of a South Asian theatre influenced other South Asians to set-up businesses in the area. Thus, the ethnic economy of the India Bazaar was created. The residential succession model's application to ethnic entrepreneurship explains the first phase of South Asian commercial settlement in the Gerrard/Coxwell region but no other theories are able to explain the ability of the India Bazaar to persist as a South Asian commercial space, situated in a non-coethnic neighbourhood. The study shows that the ethnic economy of the India Bazaar persisted because it was able to adapt to the mainstream, without alienating its traditional South Asian customer base, in addition to accommodating the surrounding area's residential concerns and the instalment of a formally institutionalized entity to facilitate the ethnic strategies of the India Bazaar (i.e. Gerrard India Bazaar BIA). The study shows that mainstream interest in the India Bazaar has been present from the beginning. However, this interest needs to be maintained and taken advantage of, in order to supplement the decrease in South Asian clientele to rival shopping areas.

The analysis reveals that despite its initial boom of the India Bazaar's commercial identity, its atypical development of a traditional ethnic economy left it more vulnerable to the 
effects of structural changes which could have been counteracted had there been a presence of institutional completeness, ethnic solidarity and ethnic strategies that accompany traditional ethnic economies. On the other hand, its distance from a substantial geographic concentration of South Asians has created an ideal opportunity to attract customers from the general population. The presence of formal institutions in the area that cater specifically to the South Asian ethnic entrepreneur is increasing, indicating a higher level of institutional completeness in the area. Specifically, the establishment of the Gerrard India Bazaar BIA consisting of businesses in the area banding together for the same goal of ensuring the sustained economic success of the India Bazaar in addition to the financial institution in the area that is specifically geared towards South Asians and South Asian entrepreneurial activity. As South Asian residential settlement patterns continues to move towards residential dispersal suburbanization, it will be a long time before a substantial residential South Asian presence is realized in the Gerrard/Coxwell area. That said, valiant efforts by the South Asian merchants to be inclusive of the area's residents have been well received. This could indicate that a development of residential solidarity to the India Bazaar instead of ethnic solidarity can parallel the protected market experienced by ethnic businesses operating within an ethnic enclave economy. 


\section{Glossary}

\section{Theoretical Definitions}

Enclave: a community that consists of residences and businesses culturally distinct from the area by which it is surrounded (Portes \& Bach, 1985; Zhou, 1992).

Enclave economy: an economy based on ethnic resources and cultural practices that primarily involves entrepreneurs and clients of the same ethnic group (Portes \& Bach, 1985; Zhou, 1992).

Ethnic entrepreneur: a business owner of a particular ethnic background that shares a cultural background or migration experience with their clients or physical space of business (Waldinger et al., 1985).

Ethnic enterprise: a business owned by an individual of a particular background that caters to customers of similar background (Waldinger et al., 1985).

Ethnic economy: "to a subset of enterprises due to efforts of a specific ethnic group", not to be confused with an immigrant economy that refers to the subeconomy of businesses created and maintained by immigrant members of a society (Lo et al., 2001, p.2).

Opportunity structure: external factors that can limit or promote the activities of immigrant entrepreneurs, such as policies that concern establishment, ownership, operation and market conditions that favour products and services oriented towards co-ethnics and non-ethnics (Lo et al., 2004; Aldrich \& Waldinger, 1990). 
Group characteristics: differences among ethnic groups based on certain elements that predispose the group. Group characteristics consist of features such as selective migration, culture, aspiration levels, resource mobilization, ethnic social networks, and general organizing capacity (Aldrich \& Waldinger, 1990).

Institutional completeness: based on ethnic communities where, complex, neighbourhood based networks lie on a continuum varying from an informal network of interpersonal relations to a community that consists of both formal and informal organizations, in such a case the higher the organization density of an ethnic community, the higher the institutional completeness ( Breton, 1964; Aldrich \& Waldinger, 1990). 


\section{References}

Acarya, M. (1997, July 21). Smell of incense, rustle of silk, Little India a feast for the senses. Toronto Star.L13.

Aldrich, H., \& Waldinger, R. (1990). Ethnicity and entrepreneurship. Annual Review of Sociology, 16(1), 111-135.

Bach, R. L., \& Portes, A. (1985). Latin Journey: Cuban and Mexican Immigrants in the United States. Berkeley: University of California Press.

Bain, J. (2003, May 28). Finally, a food festival in Gerarrd India Bazaar. Toronto Star.

Balakrishnan, T., \& Gyimah, S. (2003). Spatial residential patterns of selected ethnic groups: significance and policy implications. Canadian Ethnic Studies, 35(1), 113-134.

Barrett, G. A., Jones, T. P., \& McEvoy, D. (2001). Socio-economic and policy dimensions of the mixed embeddedness of ethnic minority business in Britain. Journal of Ethnic and Migration Studies, 27(2), 241-258.

Bauder, H. (2008). Explaining attitudes towards self-employment among immigrants: A Canadian case study. International Migration, 46(2), 109-133.

Bauder, Harald and Angelica Suorineni. 2010. Toronto's Little India: A Brief Neighbourhood History. Toronto: Ryerson University.

Bazaar features six restaurants. (1980, November 14). Ward 8 News.

Breton, R. (1964). Institutional completeness of ethnic communities and the personal relations of immigrants. American Journal of Sociology, 70(2), 193-205. 
Bonacich, E., \& Model, J. (1980). The Economic Basis of Ethnic Solidarity: Small business in the Japanese American community. Berkley: University California Press.

Brouse, C. (2005, September). Indian Summer. Toronto Life, 11, 29-38.

Bruzal, K. (1982, September 24). Caribbean foods at new East Indian mall. Contrast.

Capeleci, S. (1997, October 28). An Eastern primer. Toronto Star.

Creswell, J. (2009). Research Design (3rd Edition)[3E]; Qualitative, Quantitative, and Mixed Methods Approaches [Research Design]. London: Sage.

Fraser, J. (2003, August 22). Pakistan celebrates I-day. India Journal.pp.6-7.

Gerrard India Bazaar News. (1982). [Newsletter]. Toronto, ON: No Author.

Gillham, B. (2000). Case Study Research Methods (Real World Research). New York: Continuum International Publishing Group.

Hiebert, D. (2004). Canada: A false consensus. Immigrant entrepreneurs: Venturing abroad in the age of globalization (1st ed., pp. 39-60). Paris: Berg Publishers.

Hou, F. (2006). Spatial assimilation of racial minorities in Canada's immigrant gateway cities. Urban Studies, 43(7), 1191-1213.

Hou, F., \& Milan, A. (2003). Neighborhood ethnic transition and its socio-economic connections. The Canadian Journal of Sociology, 28(3), 387-410.

Hutsul, C. (2004, January 18). Subcontinental drift. Toronto Star.B1-B2.

Jones, T., \& Ram, M. (2003). South Asian businesses in retreat? The case of the UK . Journal of Ethnic and Migration Studies, 29(3), 485-500. 
Kidd, K. (2009, March 8). The star unveils unique map of neighborhoods. Toronto Star.

Retrieved January 28, 2010, from http:/www.thestar.com/news/gta/article/598502--thestar-unveils-unique-map-of-neighborhoods

Kloosterman, R., \& Rath, J. (2001). Immigrant entrepreneurs in advanced economies: mixed embeddedness further explored . Journal of Ethnic and Migration Studies, 27(2), 189201.

Kohane, J. (2005, August 18). Toronto's diversity presents opportunity. Business Edge, 6 . Retrieved May 2, 2010, from http://www.businessedge.ca/archives/article.cfm/torontosdiversity-presents-opportunity-10288

Leroy, I. (1978, July 20). Mall on Gerrard St. E may solve several problems. Ward 8 News.

Li, P. (2001). Immigrants' Propensity to self-employment: Evidence from Canada. International Migration Review, 35(4), 1106-1128.

Light, I. (2004). Immigration and ethnic economies in giant cities. International Social Science Journal, 56(181), 385-398.

Light, I., \& Rosenstein, C. (1995). Race, Ethnicity, and Entrepreneurship in Urban America (Sociology and Economics). New York: Aldine De Gruyter.

Lindsay, C. (n.d.). The South Asian Community in Canada : Product main page. Statistics Canada: Canada's national statistical agency/Statistique Canada : Organisme statistique national du Canada. Retrieved March 12, 2010, from http://www.statcan.gc.ca/bsolc/olc-cel/olc-cel?lang=eng\&catno=89-621-X2007006 
Lo, L., Preston, V., Wang, S., Reil, K., Harvey, E., \& Siu, B. (2001). Immigrants' economic status in Toronto: Rethinking settlement and integration patterns. CERIS-Toronto, 3(5), $1-95$.

Marger, M., \& Hoffman, C. (1992). Ethnic enterprise in Ontario: Immigrant participation in the small business sector. International Migration Review, 26(3), 968-981.

Mills, D., Durepos, R., \& Wiebe, E. (2009). Encyclopedia of case study research. Thousand Oaks: Sage Publications, Inc.

Mobility and migration. (n.d.). Statistics Canada: Canada's national statistical agency/ Statistique Canada : Organisme statistique national du Canada. Retrieved August 11, 2010, from

Myles, J., \& Hou, F. (2003, July 30). Neighborhood attainment and residential segregation among Toronto's visible minorities : Product main page. Statistics Canada: Canada's national statistical agency / Statistique Canada : Organisme statistique national du Canada. Retrieved February 17, 2010, from http://www.statcan.gc.ca/bsolc/olc-cel/olccel?catno=11F0019MIE2003206\&lang=eng

Nain, A. (2004, February 6). Little India now woes the mainstream. India Abroad.

Oliveira, L. (2000). India Bazaar: The crossroads. (Undergraduate thesis). University Of Toronto.

Paradkar, B. (2000, January 18). Death of Gian Naaz, Gian (John) Naaz brought best of India to Torotno. Toronto Star. B5.

Parent, B. (1994, Febrruary 27). Corner store fights to survive. Toronto Star. 
Peach, C. (2006). South Asian migration and settlement in Great Britain, 1951--2001. Contemporary South Asia, 15(2), 133-146.

Portes, A., \& Jensen, L. (1989). The enclave and the entrants: Patterns of ethnic enterprise in Miami before and after Mariel. American Sociological Review, 54(6), 929-949.

Price, M., \& Chacko, E. (2009). The Mixed embeddedness of ethnic entrepreneurs in a New Immigrant Gateway. Journal of Immigrant and Refugee Studies, 7(3), 328-346.

Qadeer, M. (1999). 'The bases of Chinese and South Asian merchants' entrepreneurship and ethnic Enclaves. Ceris Working Paper , 9. Retrieved February 17, 2010, from http://ceris.metropolis.net/Virtual\%20Library/economic/Qadeer1/qadeer2.html

Qadeer, M., \& Kumar, S. (2010). Evolution of ethnic enclaves in the Toronto Metropolitan Area. Journal of Internal Migration and Integration, $11(3), 315-339$.

Raijman, R., \& Tienda, M. (2000). Immigrants' pathways to business ownership : A comparative ethnic perspective . International Migration Review, 34(131), 682-706.

Ram, M., Jones, T., Abbas, T., \& Sanghera, B. (2002). Ethnic minority enterprise in its urban context: South Asian restaurants in Birmingham. International Journal of Urban and Regional Research, 26(1), 24-40.

Rangaswamy, P. (2007). South Asians in Dunkin' Donuts: Niche development in the franchise industry . Journal of Ethnic and Migration Studies, 33(4), 671-686.

Razin, E., \& Light, I. (1998). Ethnic entrepreneurs in America's largest metropolitan areas. Urban Affairs Review, 33(3), 332-360. 
Ruddin, P. L. (2006). You can generalize stupid! social scientists, bent flyvbjerg, and case study methodology . Qualitative Inquiry, 12(4), 797-812.

Snider, B. (1984, July 4). B.I.A. business community eligible for area improvement funds. The Advocate.

Stake, R. E. (1995). The Art Of case study research. Thousand Oaks: Sage Publications, Inc.

Stein, D. L. (1984, July 16). Immigrants help revive Riverdale. Toronto Star.

Teixeira, C. (2001). Community resources and opportunities in ethnic economies: A case study of Portuguese and Black entrepreneurs in Toronto. Urban Studies, 38(11), 2055-2078.

Teixeira, C. (2007). Residential experiences and the culture of suburbanization: A case study of Portuguese homebuyers in Mississauga. . Housing Studies, 22(4), 495-521.

Thibodeau, S. (2007, November 21). ICICI Bank Canada continues aggressive growth with new branch in Mississauga . ICICI Bank Canada. Retrieved August 2, 2010, from www.newswire.ca/en/releases/archive/November2007/21/c2827.html

Tran, K., Kaddatz, J., \& Allard, P. (2005). South Asians in Canada: Unity through diversity. Canadian Social Trends, Fall 2005(78). Retrieved February 17, 2010, from http://www.statcan.gc.ca/bsolc/olc-cel/olc-cel?catno=11-008XIE2005002\&lang $=$ eng\&issnote $=1$

Walcott, H. (1990). On seeking and rejecting validity in qualitative research. Qualitative inquiry in education: The continuing debate (pp. 234-318). New York City: Teacher`s College Press. 
Waldinger, R. (1986). Immigrant Enterprise: A critique and reformulation. Theory and Society, $15(1.5), 249-285$.

Waldinger, R. (1993). The two sides of ethnic entrepreneurship. International Migration Review, 27(3), 692-701.

Welcome to ICICI Bank Canada. (n.d.). ICICI Bank Canada. Retrieved August 2, 2010, from http://www.icicibank.ca/abouticicibank/newsreleases/article13.htm

Yin, R. (2008). Case study research: Design and methods (Applied Social Research Methods) (Fourth Edition ed.). Thousand Oakș: Sage Publications, Inc.

Yin, R. K. (2003). Case study research: Design and methods, Third Edition, Applied Social Research Methods Series, Vol 5 (3rd ed.). Thousand Oaks: Sage Publications, Inc.

Zenner, W. P. (1991). Minorities in the middle: A cross-cultural analysis (S UN Y Series in Ethnicity and Race in American Life). Albany, New York: State University Of New York Press.

Zhou, M. (1995). Chinatown: The socioeconomic potential of an urban enclave (Conflicts in Urban and Regional Development). Philadelphia: Temple University Press.

Zhou, M. (2006). The significance of ethnicity in immigrant enterprises. Sociological Forum, $21(3), 505-510$. 